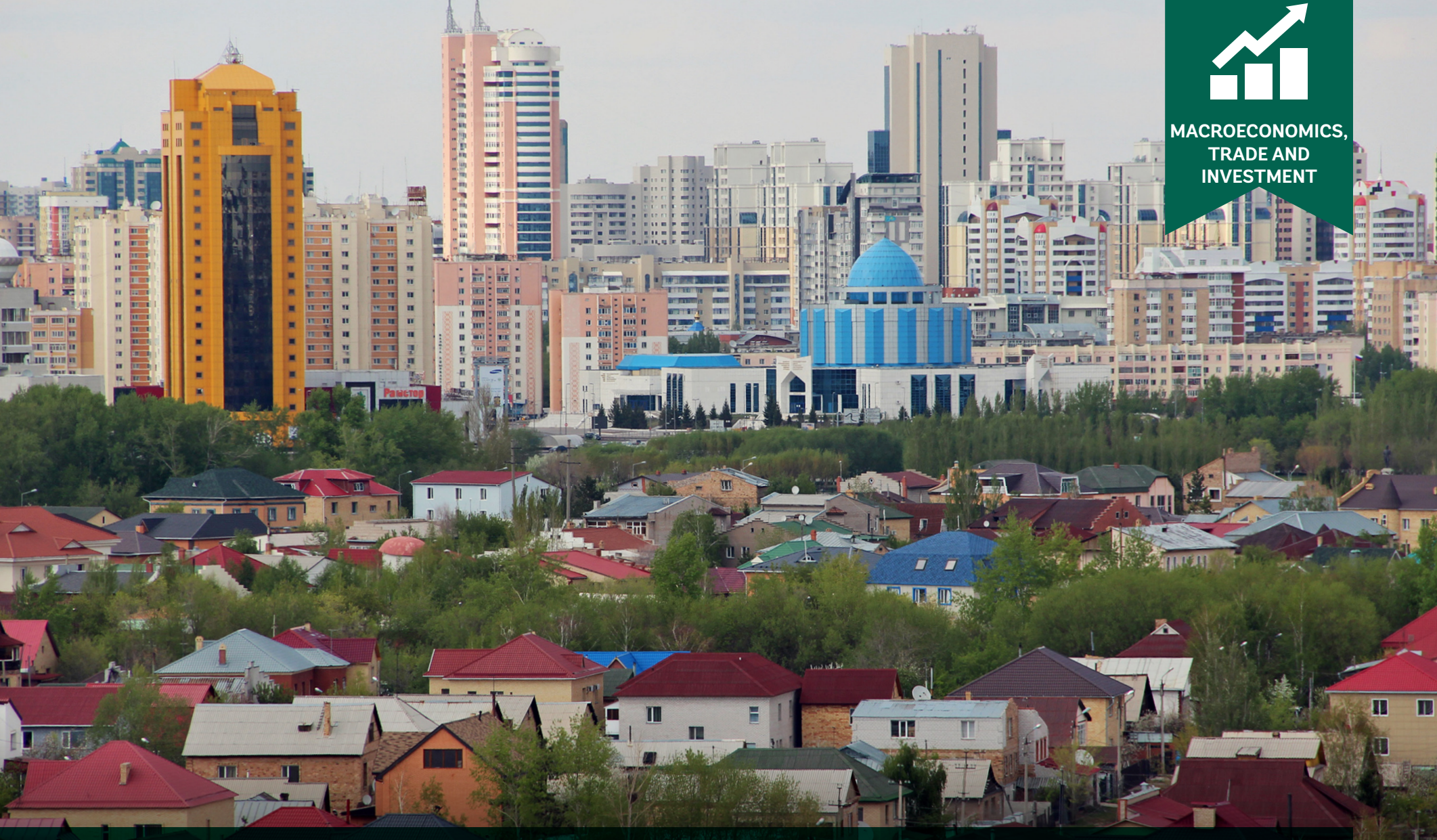

MACROECONOMICS, TRADE AND INVESTMENT

EQUITABLE GROWTH, FINANCE \& INSTITUTIONS INSIGHT
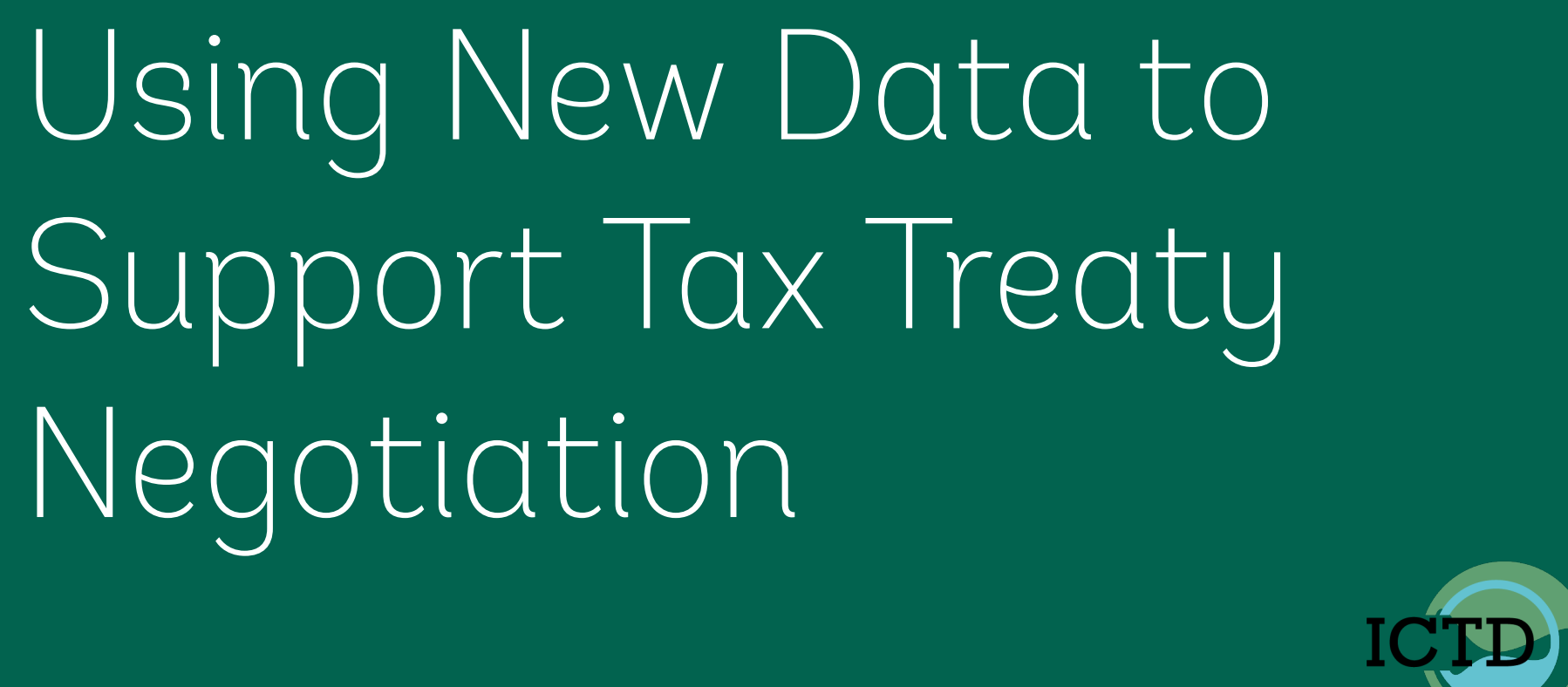

Martin Hearson

Marco Carreras Anna Custers 


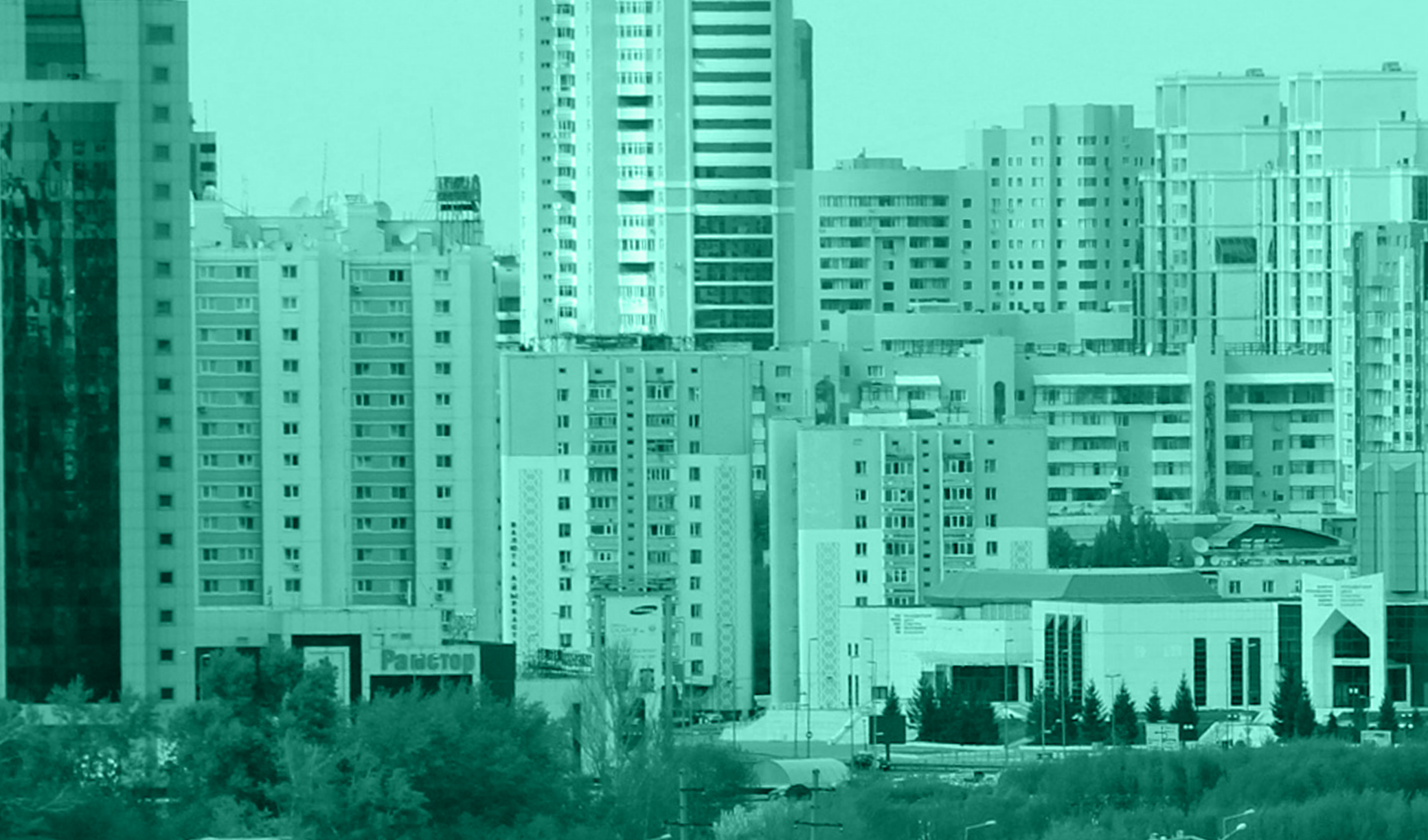

$63^{2}{ }^{2}$

iit?

IIIIII I I $m$ II II II II

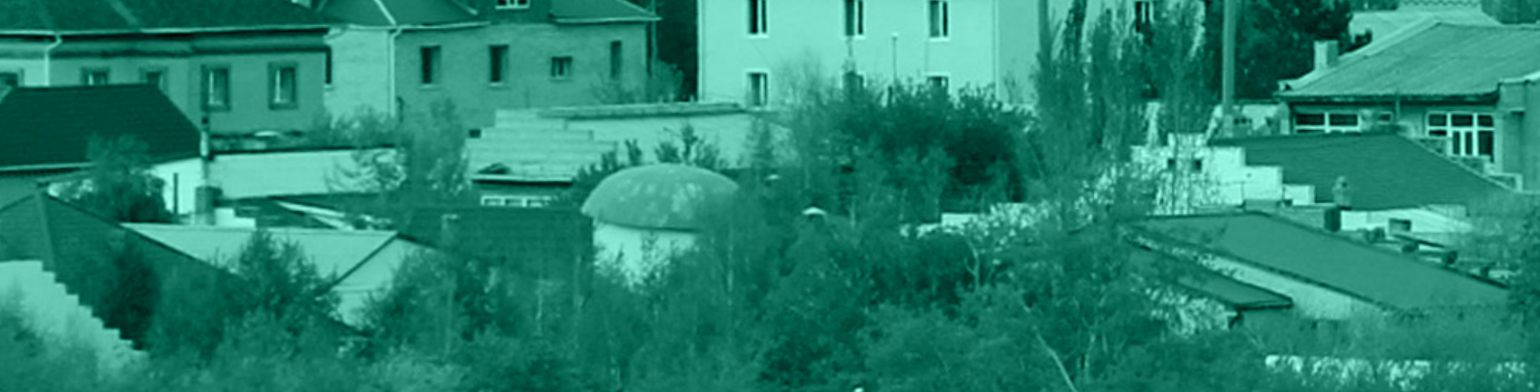

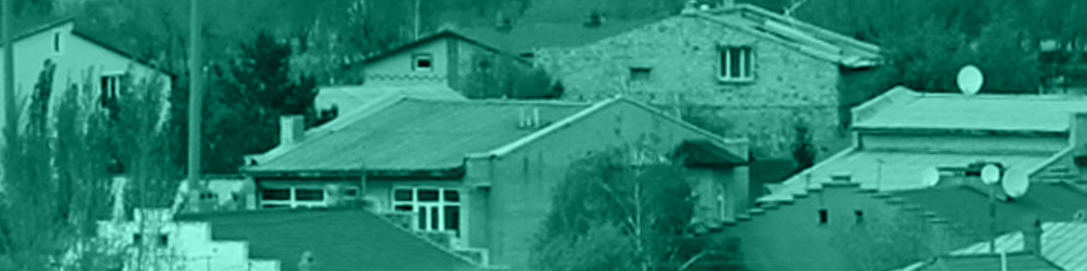
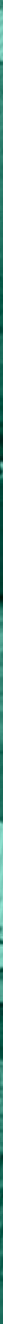
(C) 2021 International Bank for Reconstruction and Development / The World Bank 1818 H Street NW, Washington DC 20433

Telephone: 202-473-1000; Internet: www.worldbank.org

Some rights reserved.

This work is a product of the staff of The World Bank with external contributions. The findings, interpretations, and conclusions expressed in this work do not necessarily reflect the views of The World Bank, its Board of Executive Directors, or the governments they represent. The World Bank does not guarantee the accuracy of the data included in this work. The boundaries, colors, denominations, and other information shown on any map in this work do not imply any judgment on the part of The World Bank concerning the legal status of any territory or the endorsement or acceptance of such boundaries.

Nothing herein shall constitute or be considered to be a limitation upon or waiver of the privileges and immunities of The World Bank, all of which are specifically reserved.

Rights and Permissions

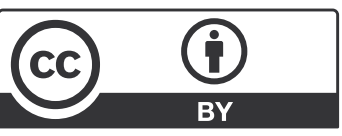

This work is available under the Creative Commons Attribution 3.0 IGO license (CC BY 3.0 IGO), http:// creativecommons.org/licenses/by/3.0/igo. Under the Creative Commons Attribution license, you are free to copy, distribute, transmit, and adapt this work, including for commercial purposes, under the following conditions:

Attribution-Please cite the work as follows: World Bank. 2021. "Using New Data to Support Tax Treaty Negotiation". MTI Insight. World Bank, Washington, DC. License: Creative Commons Attribution CC BY 3.0 IGO.

Translations-If you create a translation of this work, please add the following disclaimer along with the attribution: This translation was not created by The World Bank and should not be considered an official World Bank translation. The World Bank shall not be liable for any content or error in this translation.

Adaptations - If you create an adaptation of this work, please add the following disclaimer along with the attribution: This is an adaptation of an original work by The World Bank. Views and opinions expressed in the adaptation are the sole responsibility of the author or authors of the adaptation and are not endorsed by The World Bank.

Third-party content-The World Bank does not necessarily own each component of the content contained within the work. The World Bank therefore does not warrant that the use of any thirdparty-owned individual component or part contained in the work will not infringe on the rights of those third parties. The risk of claims resulting from such infringement rests solely with you. If you wish to reuse a component of the work, it is your responsibility to determine whether permission is needed for that reuse and to obtain permission from the copyright owner. Examples of components can include, but are not limited to, tables, figures, or images.

All queries on rights and licenses should be addressed to World Bank Publications, The World Bank Group, 1818 H Street NW, Washington, DC 20433, USA; e-mail: pubrights@ worldbank.org. 


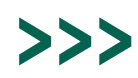

\section{Contents}

1. Tax Treaties: A Global Policy Issue 7

2. The Role of Data in Tax Treaty Making 10

3. A New Tax Treaties Dataset 13

4. Historical Legacies, Current Trends 17

5. Replication Study: Tax Treaties and FDI 29

6. Conclusion 33

7. Appendix A 34

8. References 35

$>>$

\section{Acknowledgements}

Martin Hearson: Institute of Development Studies, Brighton, UK, m.hearson@ids.ac.uk; Marco Carreras: Institute of Development Studies, Brighton, UK, M.Carreras@ids.ac.uk; Anna Custers: World Bank Group, acusters@worldbank.org. This work was funded by the World Bank through the Global Tax Program Trust Fund. The findings, interpretations, and conclusions expressed in this paper are entirely those of the authors. They do not necessarily represent the views of the World Bank and its affiliated organizations or those of the Executive Directors of the World Bank or the governments they represent. We thank Vincent Arel-Bundock, Chiara Bronchi, Patricia Ann Brown, Ana Cebreiro Gómez, and Norbert Roller for their review, inputs, and guidance. 


\section{MT NSIGH'}

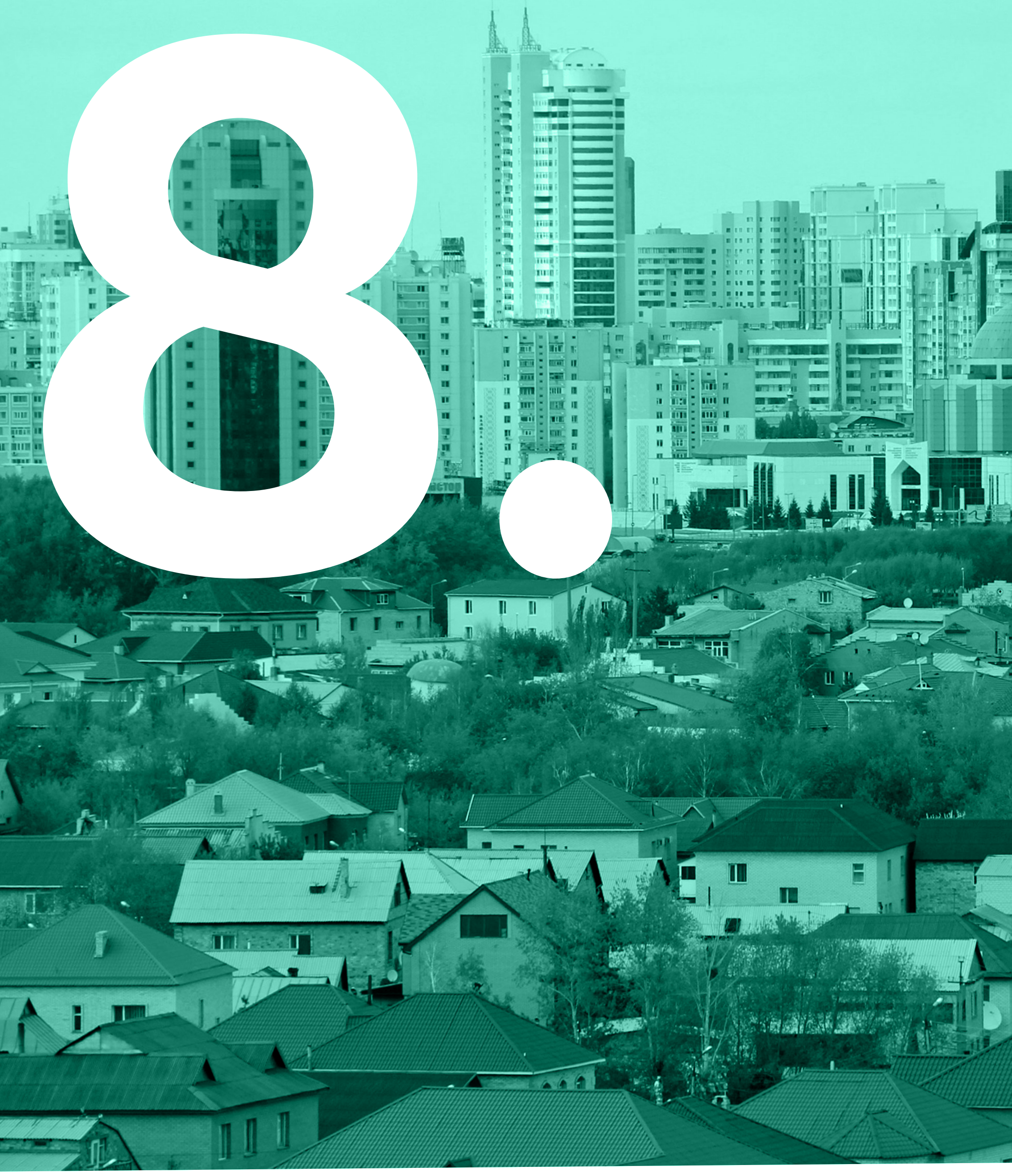



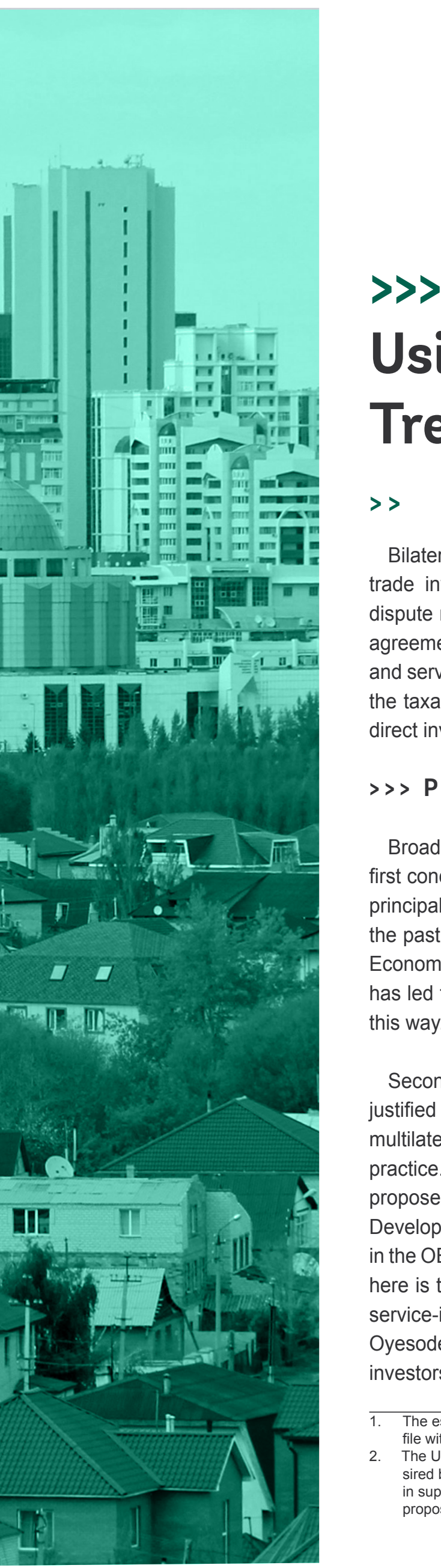

\title{
Using New Data to Support Tax Treaty Negotiation
}

\author{
$>$ TAX TREATIES: A GLOBAL POLICY ISSUE
}

Bilateral tax treaties are intended to create a stable and attractive tax environment, encouraging trade investment while providing revenue authorities with tools for mutual assistance and dispute resolution. There are over 3,000 such bilateral tax treaties. However, these negotiated agreements can also limit states' ability to tax income earned within their borders by investors and service providers from the treaty partner, often referred to as their "taxing rights." They affect the taxation of most cross-border activity, which makes up an estimated 80 percent of foreign direct investment (FDI). ${ }^{1}$

\section{$\gg$ POLICY DEBATE ON TWO FRONTS}

Broadly speaking, policy debates concerning tax treaties divide into two major categories. The first concerns the misuse of treaties to obtain benefits not intended when they were concluded, principally by "treaty shopping" via investment hubs. Public debate about tax avoidance over the past decade -in tandem with the work of the Group of Twenty (G-20) and Organisation for Economic Co-operation and Development (OECD) on base erosion and profit shifting (BEPS) has led to changes in tax treaty norms designed to prevent the treaties from being exploited in this way.

Second, questions are arising as to whether the revenue costs of curbing taxing rights are justified by any gains. Such questions are relevant both at the level of norms embodied in multilateral model treaties and when considering the bilateral treaties that countries negotiate in practice. Illustrating this concern are changes to model treaties such as the new Article $12 \mathrm{~A}$ and proposed Article 12B of the United Nations (UN) Model Double Taxation Convention between Developed and Developing Countries ("UN model"), as well as the proposal under consideration in the OECD/G-20 Inclusive Framework on BEPS (IF) to create a "new taxing right."2 The tension here is typically styled as a compromise between the taxing rights of the "source" (capital and service-importing) and "residence" (exporting) jurisdictions (Brooks and Krever 2015; EyitayoOyesode 2020). In many cases, however, curbs on source taxing rights accrue to multinational investors rather than to residence country governments (Zolt 2018).

1. The estimate covers the period 2014 to 2018. Javier Garcia-Bernardo, personal communication, September 21, 2020. On file with the authors.

2. The UN Model "seeks to assist countries in drafting and negotiating bilateral tax treaties, with a view to maintaining the desired balance between obtaining more tax revenue from foreign investment and preserving [an] investment-friendly climate, in support of their development goals" (Trepelkov 2014). The new Article 12A refers to "Fees for Technical Services" and the proposed Article 12B to "Income from Automated Digital Services." 
$\gg>$ POLICY-DRIVEN NEEDS FOR DATA

These policy debates have exposed a growing gap in the availability of policy-relevant data and research. The demand for such analysis is threefold.

\section{$\gg$ NEED FOR TREATY DEVELOPMENT AND REVISION}

First, governments are reexamining their existing treaty networks and developing treaty policies, spurred on in part by growing attention from campaigners (ActionAid 2016; Alencar, Avan, and Olwenyi 2020). In Africa, treaties with Mauritius have been terminated by the governments of Senegal, Rwanda, South Africa, and Zambia. Argentina and Mongolia are among others to have terminated treaties with investment hubs in recent years. The Netherlands signaled a willingness to renegotiate its tax treaties with low- and middle-income countries (LMICs) and to take a more flexible approach in areas such as withholding tax (WHT) rates, while Ireland issued a public consultation on its treaty policy toward lowerincome countries.

The age of many lower-income countries' treaties with OECD countries is especially of concern given the improvements to treaty norms in recent years. Half the tax treaties in force in lower-income countries today are more than 20 years old, and one-tenth were concluded before 1980-when the first UN Model Tax Convention was published-and have not been updated since. A handful of these even predate the lower-income country's independence from colonial rule. It is a significant task to analyze an aging treaty network and determine the best course of action, and countries will need to identify the highest-risk treaties on which to focus as well as the realistic potential for improvement based on precedent.

\section{〉 NEED FOR COST-BENEFIT ANALYSIS}

A second need for new data is to offer countries better guidance about the potential costs and benefits of tax treaties. For most lower-income countries, the constraints on taxing rights are a straight revenue cost in static terms, mitigated by the hope that the treaty will stimulate investment and in turn increase welfare and expand the tax base. Competition to attract inward investment has clearly motivated decisions to conclude tax treaties (Barthel and Neumayer 2012; Hearson 2021), and some research suggests that treaty shopping may create added pressure on countries to revisit their tax treaty policy and therefore to negotiate new agreements to take back control of their fiscal policy (Arel-Bundock 2017).
Yet what is in doubt is the extent to which any such gains justify the revenue forgone by the source country (Leduc and Michielse 2021). As noted tax lawyer and scholar Eric Zolt argues, tax treaties are a form of tax incentive and should be analyzed using the same tools (Zolt 2018). To that end, there are two sides to the equation: costs and benefits. It has become relatively common to estimate the costs of restrictions on dividend and interest withholding, usually in static terms, but with some estimates that take into account behavioral change (Balabushko et al. 2017; Janský and Šedivý 2018; McGauran 2013). Aside from cost estimates that focus on the presence or absence of a treaty (Beer and Loeprick 2021), there have been no other attempts to quantify the costs of various treaty provisions such as permanent establishment (PE) definitions.

As for the benefits, a wave of recent scholarship (discussed in section 2 of this paper) has deployed network analysis techniques and microdata to attempt to measure the real investment-promotion effects of particular treaty provisions, including in regard to treaty shopping. Again, these attempts have so far been largely limited to dividend and interest withholding and to FDI. Thus, when countries make decisions about tax treaties, they have precious little evidence concerning the costs and benefits of other restrictions on their taxing rights.

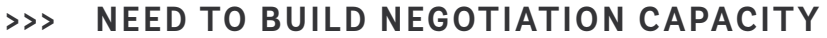

Finally, lower-income countries need more easily accessible data to strengthen their capacity for negotiation and renegotiation. The publication of a revised UN Manual for the Negotiation of Bilateral Tax Treaties between Developed and Developing Countries (UN 2019) and the Platform for Collaboration on Tax's "Toolkit on Tax Treaty Negotiations" (PCT 2021) are examples of the renewed focus on this topic, as is the provision of technical assistance through Tax Inspectors Without Borders. ${ }^{3}$ At the regional level, bodies such as the African Tax Administration Forum (ATAF) and the Inter American Centre of Tax Administrations (CIAT) have invested in tools and training for their members in treaty negotiation, and the number of regional model treaties is growing.

Still, some lower-income countries continue to negotiate and renegotiate costly tax treaties. For example, in recent years Benin, Burundi, Equatorial Guinea, The Gambia, Guinea, Mauritania, and Nigeria have concluded treaties that eliminate all or most WHT rates. Kenya's 2012 treaty with Mauritius was struck down by its High Court following a challenge from civil society organizations (Ogembo 2019) and has now

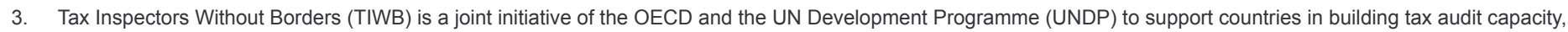
with a focus on multinational enterprises' compliance. For more information, see the TIWB website: http://tiwb.org/. 
been renegotiated in a much stronger form. Zambia's nowterminated treaty with Mauritius had been signed as recently as 2011. Stronger, data-driven analysis will help countries to develop tax treaty policies that stipulate whom they will negotiate with, on what terms, and how to establish their positions and prepare for negotiations, including by analyzing precedent (Mutava 2019).

\section{$\gg$ CONTRIBUTIONS OF THIS PA- PER}

This paper introduces the new Tax Treaties Explorer dataset-developed with support from the World Bank and the Intergovernmental Group of 24 on International Monetary Affairs and Development (G-24)_and explores some of its insights regarding these three data gaps. Building on prior work published by ActionAid and the International Centre for Tax and Development (ICTD) (Hearson 2016), the new dataset captures 28 clauses, most of them reflecting the balance between source and residence taxation, across almost every tax treaty signed by low- and middle-income economies.

This dataset enables, for the first time, broad comparisons and analyses between countries and over time for over 2,500 treaties plus amending instruments. It offers the potential for new research into the impact of specific treaty provisions beyond dividend and interest withholding taxes. The dataset is accompanied by an online tool (available at http://www.treaties.tax) that acts as an accessible entry point to understand treaties in comparative context.
The next section discusses the state of knowledge on tax treaties in LMICs; introduces the dataset in section 3; and presents some initial descriptive findings, illustrating how the data might be used, in section 4 . Section 5 includes a replication study that demonstrates how the dataset can help to refine existing knowledge about the impacts of tax treaties. Starting from the model of Barthel et al. (2010), which finds a relationship between tax treaties and FDI, we replace the binary measure of the presence of a treaty with indexes from the dataset. This tentative analysis suggests that more residence-based treaties exert a stronger positive impact on FDI but that this effect is driven by lower withholding tax (WHT) rates, not by other treaty provisions. 


\section{$\gg$ THE ROLE OF DATA IN TAX TREATY MAKING}

\section{\> BETTER DATA, BETTER TREATY POLICY AND PREPARATION FOR NEGOTIATIONS}

Data are essential to underpin a strong negotiating position. Precedent in a country's own treaty network, that of its negotiating partner, and trends in treaty negotiations more broadly can all either reinforce or undermine a position. As the Platform for Collaboration on Tax's Toolkit on Tax Treaty Negotiations notes, even before negotiations begin, "a country's decision to negotiate a tax treaty should be based on an analysis of the ... [other country's] recent tax treaties in order to identify the main elements of its tax treaty policy" (PCT $2021,7)$. For example, the United States will not agree to a tax sparing clause-a "deal-breaker" preventing negotiations with some LMICs (Brown 2020). And although the United Kingdom once routinely offered an article on withholding taxes on fees for technical services to lower-income countries, in recent years it has refused to do so (Hearson 2017).

Guidance on treaty negotiations points to the importance of preparing for negotiations by reviewing one's own recent treaties, as well as those of the treaty partner, with countries in similar regions or income groups (PCT 2021, 19; UN 2019, 28). Furthermore, outside of negotiations themselves, countries are increasingly seeking to review their existing networks to identify vulnerabilities and opportunities to strengthen them. Because many lower-income countries currently lack policies on tax treaty negotiation, such reviews should strengthen the process of treaty making and the outcomes of negotiations (Mutava 2019).

Data availability—or the lack thereof-imposes constraints on governments and other stakeholders who are attempting to analyze treaty networks, whether their own, those of potential treaty partners, or those of their neighbors and competitors. Although treaty texts often can be obtained from government websites, they are not always easy to find and may not be translated into an accessible language. Subscription databases have more comprehensive coverage, but access may be prohibitively expensive. In any case, the analysis of a large number of treaties requires specialized knowledge and can be time-consuming. Studying the network of each current and potential treaty partner rapidly becomes a major challenge.

Some information, most commonly on WHT rates, has been extracted from treaties and made available in a quickreference tabulated format by various organizations, but such data have downsides:
- They encourage a focus on quantitative treaty provisions at the expense of others that may be just as pertinent.

- Their utility as tools for quick-reference comparison frequently break down when rates are stratified in ways not captured by basic templates-for example, if there are multiple rates for different types of royalty.

- The variations in wording found across many treaties mean that a simple search for specific terms in a treaty's text cannot reliably establish the presence or absence of a particular provision.

- $\quad$ Taxing rights may be established in places other than those indicated by the model treaties-including protocols attached to treaties at the time of signature, or protocols and other amending instruments concluded at a later date.

Purposive interpretation across many treaties and articles therefore requires a significant investment of time.

The absence of an open database of coded treaty content means that the exercise of tabulating common standardized variations in treaties has been performed repeatedly by researchers, duplicating effort and inevitably leading to partial analyses that are usually focused on only one or several countries or clauses (Brooks 2010; Daurer 2014; Daurer and Krever 2012; Hearson and Kangave 2016; Li 2012). (For more comprehensive coverage, see Wijnen, de Goede, and Alessi 2012; Wijnen and de Goede 2013.)

Although academic research often employs a heuristic that any capital- and service-importing country will seek to retain as many source taxing rights as possible during a negotiation (Chisik and Davies 2004; Rixen 2011; Rixen and Schwarz 2009), the picture is more complex. Examining countries' actual treaty networks shows a wide variation in the content of tax treaties negotiated within the current parameters. For example, Daurer and Krever (2012) demonstrate that African countries' treaties are less source-based than those of Asian countries with the same treaty partners, while Li (2012) shows an evolution over time in the negotiated content of China's treaties.

Hearson (2018) suggests that power asymmetries and lack of negotiating experience both translate into greater restrictions on source taxing rights. Analysis by the International Monetary Fund (IMF) suggests that treaties are more likely to include a provision on capital gains on shares deriving value indirectly from immovable property if one of the signatories is a resourcerich or low-tax jurisdiction-and that such provisions are more 
common as the difference between the two jurisdictions' tax rates on capital gains increases (PCT 2020, 33).

LMICs' preferences can be observed in a variety of sources, including the contents of regional model treaties, and in published disagreements with provisions of the OECD and regional models (Vega and Rudyk 2011; West 2021). We might presume that these observed variations in preferences reflect a combination of countries' tax policy priorities at the time of signature as well as learning and capacity development, political motivations, and the power dynamics of negotiation (Hearson 2018; Kangave 2009; Mutava 2019).

\section{$\gg$ A DRIVE TO IMPROVE RESEARCH ON COSTS AND BENEFITS}

A most basic observation about the academic literature on tax treaties is that the findings concerning the costs and benefits of tax treaties are inconclusive, especially in the case of lower-income countries. Studies of the impact on FDI during the 2000s produced a mixture of positive, null, and negative results (Sauvant and Sachs 2009).

\section{\> IMPROVED APPROACHES}

In recent years, this picture has changed as researchers began to develop ever more sophisticated models (Table 1). A review of these studies points to several attributes in which new approaches improve on their predecessors:
- $\quad$ More precise sources of data. Although aggregate FDI statistics can still produce interesting findings, studies increasingly use bilateral FDI data or firm-level microdata. The latter may be preferable since bilateral FDI data have coverage and accuracy issues, especially for lower-income countries.

- Salient features of home countries' taxation of foreign income. Consideration of these features may have a material impact on the gains to investors from tax treaties. Credit systems and controlled foreign company rules, for example, may soak many of them up, diluting treaties' impact on investment to these countries.

- Models' focus on indirect investment structures. Whether for tax treaty shopping or otherwise, recent literature shows the use of network analysis to identify the most costeffective pathways for firms to repatriate income before and after a direct treaty is concluded between two countries. To do this effectively, it is necessary to consider the attributes of potential conduit jurisdictions' tax systems, as well as of their tax treaty networks.

- Consideration of treaty attributes rather than just a binary variable-that is, whether the treaty exists or not. To date, most studies attempting to estimate the investment effects of tax treaties have either disregarded the content of the treaty altogether or focused on dividend WHT rates. A few have also considered WHT rates on interest and royalty payments as well as "tax sparing" clauses. As noted in the Platform for Collaboration on Tax's toolkit, current methodologies to estimate the revenue forgone from tax treaties are also limited to restrictions on dividends, interest, and royalties WHT (PCT 2021, 9). 


\section{TA B LE 1 - Studies of the Relationship Between Tax Treaties and Investment Since 2010}

\begin{tabular}{|c|c|c|c|c|}
\hline STUDY & TYPE OF DATA & $\begin{array}{l}\text { HOME COUNTRY } \\
\text { TAX SYSTEM }\end{array}$ & $\begin{array}{l}\text { TREATY } \\
\text { SHOPPING }\end{array}$ & TREATY CONTENT CONSIDERED \\
\hline Azémar and Darmaphala (2019) & Bilaterial FDI & Yes & Yes & $\begin{array}{c}\text { Treaty binary } \\
\text { Tax sparing clauses }\end{array}$ \\
\hline Baker (2014) & Bilateral FDI & No & No & Treaty binary \\
\hline Balabushko et al. (2017) & Microdata & n.a. (Ukraine) & Yes & Dividend, interest, and royalty WHT \\
\hline Beer and Loeprick (2021) & Aggregate FDI & No & Yes & $\begin{array}{l}\text { Treaty binary } \\
\text { Dividend WHT } \\
\text { Interest WHT }\end{array}$ \\
\hline Blonigen, Oldenski, and Sly (2014) & Microdata & n.a. (US) & No & $\begin{array}{l}\text { Treaty binary } \\
\text { MAP (inferred) }\end{array}$ \\
\hline Dressler (2012) & Microdata & n.a. (Germany) & Yes & Dividend WHT \\
\hline Hong (2018) & Bilateral FDI & No & Yes & Dividend WHT \\
\hline Marques and Pinho (2014) & Microdata & Yes & No & $\begin{array}{l}\text { Treaty binary } \\
\text { Dividend WHT }\end{array}$ \\
\hline Mintz and Weichenrieder (2010) & Microdata & n.a. (Germany) & Yes & Dividend WHT \\
\hline Petkova, Stasio, and Zagler (2020) & Bilateral FDI & Yes & Yes & Dividend WHT \\
\hline van 't Riet and Lejour (2018) & Bilateral FDI & Yes & Yes & Dividend WHT \\
\hline Weyzig (2013) & Microdata & $\begin{array}{l}\text { n.a. } \\
\text { (Netherlands) }\end{array}$ & Yes & $\begin{array}{l}\text { Treaty binary } \\
\text { Dividend WHT }\end{array}$ \\
\hline
\end{tabular}

Note: $F D I=$ foreign direct investment; $M A P=$ Mutual Agreement Procedure; $n$. a. = not applicable; $W H T=$ withholding tax

\section{$\gg$ STRENGTHENING RESEARCH TO BENEFIT LMICS}

How can this body of research be strengthened to the benefit of negotiators from lower-income countries, so that they can maximize the benefits gained while minimizing the revenue forgone? Eric Zolt summarized the key questions in 2018:

While the traditional focus has been on whether developing countries should enter into tax treaties with developed countries, the better questions may be what form the treaties should take and with whom developing countries should enter into treaties. (Zolt 2018, 147)

To answer these questions, we first need better data and econometric techniques. The recent publication of studies that consider some salient features of potential treaty partners and the impact of certain treaty articles is a positive development. Yet, where studies have considered dividend withholding alongside the impact of treaties as a whole, the latter has an independent effect, indicating that other aspects of tax treaties contribute to their investment effects (Marques and Pinho 2014; Weyzig 2013). Conversely, Azémar and Darmaphala (2019) find that only treaties with a tax sparing provision had any impact on investment. A next generation of research should consider the costs and benefits of other provisions that may affect investment decisions, including other WHTs, PE definitions, and capital gains taxes as well as the benefits that accrue from having any tax treaty at all, regardless of its terms.

Second, while network analysis has permitted a focus on investment diversion via conduits, it should be remembered that the key concern for a capital-importing country is how to increase its total stock of inward investment as well as how to maximize the revenue from that stock. For example, one interpretation of research by Beer and Loeprick (2021) is that aggregate $\mathrm{FDI}$ in an economy increases, albeit alongside declining tax revenue, when firms can minimize tax costs through treaty shopping. Balabushko et al. (2017) also find a behavioral response from reducing or increasing WHT rates in treaties.

Third, research to date has largely concentrated on FDI, a choice that is certainly logical. The impact of some treaty provisions may be felt elsewhere, particularly on portfolio investment, trade in goods and services, transfers of intellectual property, and movement of people.

Fourth, the welcome inclusion of attributes of home country jurisdictions could be expanded to consider attributes of host countries. Several cross-country studies have already attempted to use host country WHT rates, but the key challenge 
here is a lack of historical data. Besides the specifics of host country tax systems that correspond to treaty provisions, a key challenge concerns the effect of tax incentives, which may limit the additional benefits of a treaty.

Fifth, and related to the preceding, research should consider the idiosyncrasies of sectors that are especially important to LMICs. The most obvious case is extractive industries, for which concession and stability agreements may substitute for the absence of a tax treaty. As the results of Blonigen,
Oldenski, and Sly (2014) suggest, firms in sectors most prone to transfer pricing controversy may value the dispute resolution and certainty aspects of tax treaties more than firms in other sectors would - though uptake of tax treaty dispute settlement in lower-income countries is rare.

\section{$\gg$ A NEW TAX TREATIES DATASET}

During 2019 and 2020, a dataset was assembled comprising 2,533 bilateral tax treaties, 8 multilateral tax treaties, 272 bilateral amending instruments, and 687 modifications through the OECD/G-20 Multilateral Instrument to Implement Treaty-Related Aspects of BEPS (MLI). ${ }^{4}$ As far as possible, the Tax Treaties Explorer dataset includes all treaties signed by 118 countries: those that are, or were until recently, LMICs; all countries in Africa, and all members of the G-24. ${ }^{5}$ Lists of treaties were compiled from the International Bureau of Fiscal Documentation (IBFD), supplemented with governments' own lists published online.

Most tax treaty negotiations use as their starting point the OECD Model Tax Convention on Income and on Capital ("OECD model") and UN model tax conventions, and almost all treaties follow a structure based on these models. Treaties based on the OECD model generally impose greater restrictions on a country's ability to tax inward investment, whereas the UN model makes amendments to the OECD model that leave more of these rights intact. In the Tax Treaties Explorer dataset, each of the fields (table 2) is based on a provision of the model treaties-whether the provision represents a difference between the UN and OECD models, a clause that is in both models but does not always appear in negotiated treaties, or a value that the models leave open to bilateral negotiations.

The dataset was developed in consultation with an advisory group of tax professionals, some of whom were experienced treaty negotiators. Of particular importance, it includes the large majority of those items listed in the Platform for Collaboration on Tax's toolkit (PCT 2021, 13).

\section{$\gg>$ ADVANCEMENTS IN THE TAX TREATIES EXPLORER DATASET}

This new dataset builds on the ActionAid Tax Treaties Dataset, published by ActionAid and the ICTD and discussed in an ICTD working paper (Hearson 2016). Benefiting from feedback on the ActionAid dataset and support to develop the revised dataset from expert advisers and other stakeholders, the new dataset represents three main improvements on the previous one:

- Much wider coverage. The dataset incorporates five times as many treaties as the earlier ActionAid Tax Treaties Dataset and uses a larger sample of LMICs-a concerted effort to code older treaties that were previously omitted because they did not follow the structure of the OECD and UN models-and includes amending protocols and multilateral treaties. Feedback from revenue officials in francophone lower-income countries, for example, stressed that including colonial-era treaties that are still in force, as well as regional multilateral agreements, was essential to provide a comprehensive picture. Nonetheless, some treaties are still uncoded, either because the text was not available in English, French, or Spanish, or because they were so different in content and structure from the modern-day model tax treaties that coding was impossible.

4. Data in this working paper apply to version 2.0.4. of the dataset. Check https://treaties.tax/data for subsequent updates.

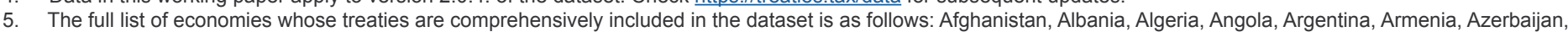

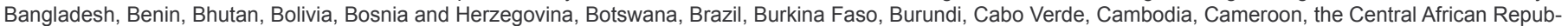

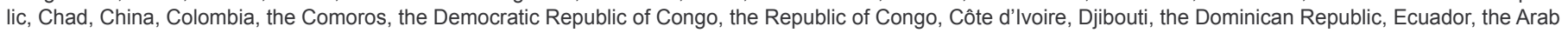

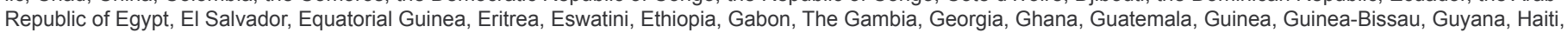
Honduras, India, Indonesia, the Islamic Republic of Iran, Iraq, Jordan, Kenya, Kiribati, Democratic People's Republic of Korea, Kosovo, the Kyrgyz Republic, the Lao

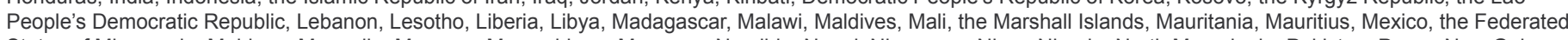

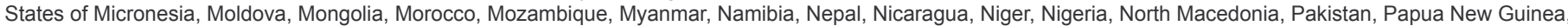
Paraguay, Peru, the Philippines, Rwanda, Samoa, São Tomé and Príncipe, Senegal, the Seychelles, Sierra Leone, the Solomon Islands, Somalia, South Africa, South Sudan, Sri Lanka, Sudan, the Syrian Arab Republic, Tajikistan, Tanzania, Thailand, Timor-Leste, Togo, Tonga, Trinidad and Tobago, Tunisia, Turkmenistan, Uganda, Ukraine, Uzbekistan, Vanuatu, República Bolivariana de Venezuela, Vietnam, West Bank and Gaza, the Republic of Yemen, Zambia, and Zimbabwe. A few of these countries are not mentioned in the dataset because they had not concluded any tax treaties as of January 1,2020. 
- $\quad$ Alteration of the provisions covered to focus on the most pertinent business taxation provisions. In particular, the WHT rates for interest on loans from financial institutions, copyright royalties, and royalties for the use of equipment are all now included as separate fields in addition to the main rates for these two categories.

- Development of an online interface. Users can interact with the data directly at http://www.treaties.tax. Experience with the ActionAid dataset indicated that manipulation of the Microsoft Excel file was a barrier to access for many users.

To ensure accuracy, each treaty was coded twice, independently, by two different members of the project team. Coders were recruited from universities with master's degree programs in law, and they were either recent graduates or current students who had completed courses in tax treaty law. The coders' early work was comprehensively checked until they achieved a satisfactory level of accuracy.

The dataset also uses a purposive interpretation, which means that coders were asked to take account of the intention of nonstandard wording rather than simply checking for the presence of specific phrases. Guidance on how to code common nonstandard formulations was prepared with support from the advisory group, and coders were asked to flag any nonstandard clauses for verification of their interpretation. The agreement rate between coders after initial data cleaning was 95.4 percent. Disagreements and queries were then resolved by the project lead, consulting with the advisory group.

\section{$\gg$ CAVEATS AND LIMITATIONS}

It is worth discussing several caveats and limitations to the dataset. To begin with, claims about provisions of individual treaties drawn from this dataset should always be checked against the treaty text, because the dataset is designed for high-level comparisons rather than to give a precise or comprehensive account of the legal position. Other caveats to keep in mind when using the dataset are coding limitations and the absence of domestic tax considerations.

\section{\ CODING LIMITATIONS}

The coding structure eliminates nuance and heterogeneity by coding each provision with a single word or number. This approach is appropriate because the dataset deliberately includes treaty provisions that appear uniformly in most treaties, but there are sometimes exceptions. For example, the dataset gives two dividend WHT rates as well as the threshold for the recipient's share of ownership that qualifies for the lower rate. Some treaties have three or more rates or use a different type of eligibility criterion for the lower rate.

Anonline code bookexplains how the mostcommon variations were treated. ${ }^{6}$ Some coding errors and inconsistencies may remain, although the double coding approach should limit their number. Where they persist, this will usually be because both coders made the same error, which is especially the case where treaties contain nonstandard wording.

Certain important clauses are also missing entirely from the dataset because of the wide variation in drafting that makes it hard to code reliably. One example involves "tax sparing" provisions within the article covering double taxation relief, which significantly influenced many negotiations by LMICs and have been found in one study to affect flows of investment (Azémar and Dharmapala 2019).

In addition, despite the aim of purposive interpretation, coding rules based on the model treaties could fail to capture the interaction between provisions included for consideration and others that may have a similar effect if drafted in a nonstandard way. Nonstandard wording also inevitably leads to some subjectivity in the interpretation of treaty provisions. Wherever possible, guidance on these issues was flagged in advance in the guidance given to coders or was applied retrospectively if issues arose during spot checks.

For example, WHTs on technical service fees (Article 12A) are usually provided for in stand-alone articles but may be included within the royalties article. In the latter case, they may simply be incorporated within the definition of royalties or included as a separate paragraph later on. They may also be provided for through a protocol appended to the treaty when it was concluded, with no mention in the main body of the treaty at all.

Another example involves Article 13 (capital gains), for which the dataset includes fields related to the inclusion of paragraphs 4 and 5 (respectively, gains on a "land rich" company and gains not in that category). This assumes that, following the UN and OECD models, this article defaults to residence taxation. In some cases, however, the article defaults to source taxation, in which case paragraphs 4 and 5 may not be required for the source country to have a taxing right over the income concerned. In cases such as these, the code book online indicates how values have been captured.

6. See https://www.treaties.tax/files/tax-treaties-dataset-coding-book.pdf. 
As discussed earlier, much useful analysis of tax treaties requires consideration of countries' domestic tax systems, which the dataset does not incorporate at this stage. For example, the WHT rates in the dataset are absolute values. Yet a 10 percent maximum in a treaty may result in considerable forgone tax revenue for a country whose domestic rate is 20 percent, whereas it would have no impact on revenues for a country whose domestic rate is 8 percent.

Article 13, paragraph 4 (gains on a "land rich" company), can facilitate the imposition of capital gains tax on indirect transfers of assets but only in the presence of appropriate provisions in the domestic tax code (PCT 2020). Conversely, in certain cases, domestic antiavoidance legislation or jurisprudence might allow for an extensive interpretation of a treaty in the absence of a paragraph such as 13(4).

Of course, the sacrifice of taxing rights is the same regardless of domestic law. A country with an 8 percent WHT rate today may have had a higher rate in the past, just as it may want to increase its rate in the future. Likewise, a country with no capital gains tax at the time it signs a treaty may subsequently introduce one.

\section{\> INDEXES THAT SUPPORT TREATY COMPARISONS}

As well as using the dataset to look across the detail of negotiated tax treaties, it can also be used to amalgamate a treaty's content into expressions of its overall protection for source taxing rights. These indexes are useful, albeit rough, starting points for treaty comparisons. To create them, each clause in the treaty was assigned a value between 0 and 1, where 1 represents a greater taxing right over inward investment. Indexes are the averages of these values over a particular group of clauses, as follows:

- Index of source taxing rights: incorporates all fields in the dataset that relate to the balance of taxing rights. It is calculated as the average of the PE, WHT, and "Other provisions" indexes. It gives a high-level overview of the treaty.

- Index of PE definition: includes fields related to PE, which refers to the threshold above which a foreign company's presence in a country becomes taxable. It is drawn from Article 5 of the model treaties.

- Index of WHT rates: averages the WHT rates in each treaty. These are taxes imposed on cross-border investment,

which treaties either prevent or limit to a maximum rate. These are Articles 10 to $12 \mathrm{~A}$ of the model treaties. Each of the four types of payment (dividends, interest, royalties, and technical service fees) receives equal weighting, but within each type, the values in the dataset are averaged.

- Index of other provisions: includes the remaining fields, drawn from Articles 7, 8, 13, 16, and 21 of the models.

- UN index: employs a strict analysis of only the provisions that vary between the UN and OECD models, as they stood in 2017. It excludes, for example, WHT rates (since these are not specified in the UN model), but it does include Article 12A ("Fees for Technical Services") or an equivalent taxing right. Shipping, where the UN model gives two options, receives half weighting.

Beyond the calculations described above, the indexes based on the dataset do not employ any weighting strategy. Defending the right to impose certain taxes will be much more important to some countries, at certain points in time, than to others. It is impossible to take this into account, and so the indexes do not attempt to establish a hierarchy of provisions. Consequently, the indexes provide high-level comparisons that point to trends meriting further investigation. 
TA B LE 2 - Tax Treaties Explorer Dataset Fields, by Index

\section{ARTICLE (PARAGRAPH)}

\section{DEFINITION ARTICLE (PARAGRAPH)}

MODEL TREATIES

Index: PE Definition

\section{$5(3)(a) C$ \\ $5(3)(a) S$ \\ $5(3)(b)$ \\ $5(4)(a)$ \\ 5(4)(b) \\ $5(5)(b)$}

$5(6)$

5(7)

Index: WHT Rate

10(2)(a)Q

10(2)(b)

11(2)

11(2)F

12(2)

12(2)C

12(2)E

$12 \mathrm{~A}$

Index: Other Provisions

7(1)(b\&c)

7(3)

8(2)

13(4)

13(5)

14

16(2)

21(3)

Excluded from Indexes

10(2)(a)T

25B(5)

27

29
Construction PE Length (Months)*

Supervisory Activities Associated with Construction*

Service PE Length (Months)*

No Delivery Facility Exception to PE*

No Delivery Stock Exception to PE*

Stock Agent in $\mathrm{PE}^{*}$

Insurance Broker in P*

Dependent Agent Extension to $\mathrm{PE}^{*}$

Qualifying [FDI] Dividend WHT Rate (\%)

Other [Portfolio] Dividend WHT Rate (\%)

General Interest WHT (\%)

Interest WHT Rate Applying to Loans from Banks and Financial Institutions

General Royalties WHT Rate (\%)

Royalties WHT Rate Applying to Payments for Copyright (\%)

Royalties WHT Rate Applying to Payments for the Use of Equipment (\%)

Management or Technical Service Fees WHT Rate (\%)*

Limited Force of Attraction*

No Deduction for Payments to Head Office*

Source Shipping Right*

Source Capital Gains on "Land Rich" Company*

Source Capital Gains on Shares Other than those Covered by 13(4)*

Independant Personal Services Included*

Source Taxation of Earnings by Top-Level Managerial Officials*

Source Taxation of Other Income*

Threshold for Qualified Dividends

Mandatory Binding Arbitration

Assistance in Tax Collection

Entitlement to Benefits

Source: Tax Treaties Explorer dataset, https://www.treaties.tax/.

Note: The dataset's overall "Index of source taxing rights" is a high-level overview of taxing rights, calculated as the average of the PE, WHT, and "Other provisions" indexes shown in the table. Provisions marked with an asterisk (*) are included in the UN index. FDI = foreign direct investment; PE = permanent establishment; $W H T$ = withholding tax. 


\section{$\gg$ HISTORICAL LEGACIES, CURRENT TRENDS}

Half (51 percent) of tax treaties in the Tax Treaties Explorer dataset are more than 20 years old (concluded before 2000 and not updated since), and about 10 percent date from before 1980. In this time, negotiation practice and the norms set out in the model conventions have changed significantlyin ways that strengthen treaties against abuse and, in some instances, expand source taxation rights. The new dataset allows us to develop stylized findings about these trends and clarify existing assumptions.

The charts that follow display trends over time across all treaties in the dataset. ${ }^{7}$ Solid lines represent all treaties in force at a given time, considering preindependence treaties, new treaties, renegotiations, and terminations. They show how LMICs' taxing rights are affected by all their treaties in force and the gradual impact of changes in negotiating norms. Individual dots show average values for treaties signed each year. These dots show the outcome of negotiations by LMICs and are more sensitive to trends in negotiating norms and more volatile than the average content of treaties in force, since the latter also includes treaties concluded in the past. A treaty that is reflected in the dots will only change the direction of the line when it becomes effective.

\section{$\gg$ WITHHOLDING \\ TAXES, PERMANENT ESTABLISHMENT, AND THE OVERALL BALANCE OF TAXING RIGHTS}

As an IMF analysis points out, WHT rates in new tax treaties have been "trending down" in past decades, alongside WHT and corporate income tax rates in domestic law (IMF 2014, 26). The new dataset allows us to clarify the reasons behind this finding in three ways.

First, the decline in WHT rates in the overall stock of treaties only begins in the mid-1990s because of the persistence of treaties signed in the 1980s and before with higher rates. Furthermore, the aggregate pattern in newly signed treaties is less of a downward trend and more of a structural change occurring in the early 1990s. This pattern is exaggerated by data artifacts caused by the breakup of the former USSR (Barthel et al. 2010), but it persists once they are excluded, as in the charts that follow. The drivers of this change merit further study. Overall, WHT rates in treaties peaked in 1994, and the treaty network today is on a par the rates that prevailed during the 1980s.
Second, in contrast to the decline in WHT rates, the trend across other provisions of tax treaties is toward greater retention of source taxing rights. Figure 1 shows the evolution in treaties' provisions for overall source taxing rights, showing that the overall index was increasing in value until 1994, after which it largely flattened. Underlying this early growth was the continued strengthening of source taxing rights in provisions other than WHT rates, which since 1994 has balanced out the decline in those rates. Indeed, the index measuring PE definitions shows a quite consistent rise throughout the past half century. The trends in PE and WHT point to a shift from gross to net basis taxation, which may be more challenging for resource-constrained revenue authorities (Leduc and Michielse 2021).

Third, Figure 2, which examines WHT rates in the stock of agreements in force, shows that the decline in the past three decades is most pronounced regarding dividends. Where they are provided for, rates on technical service fees have also declined, but provision for such taxes has also become much more common in treaties. In contrast, the decline in average interest and royalty rates in the stock of treaties as a whole has been relatively small, and these rates are still comparable with rates found during the 1980s. As for new treaties signed, the averages during the 1970s and 1980s were similar for qualifying dividends, interest, and royalties at 12 percent. By the 2010s, the qualifying dividends rate had fallen to an average of 7 percent compared with 9 percent for interest and royalties.

Figure 3 sheds more light on the expansion of PE definitions. Provisions allowing for source taxation of the delivery of goods are the only ones coded in the dataset to have become less common, while the others show a growth in popularity over time. The time threshold for construction and service PE definitions has also declined, as will be discussed later.

7. Countries of the former USSR have been excluded from this quantitative analysis because of their distorting effect on historical data (Barthel et al. 2010). 
$>>>$

FIG U R E 1 - Changes in Indexes Measuring the Overall Balance of Taxing Rights, 1970-2019

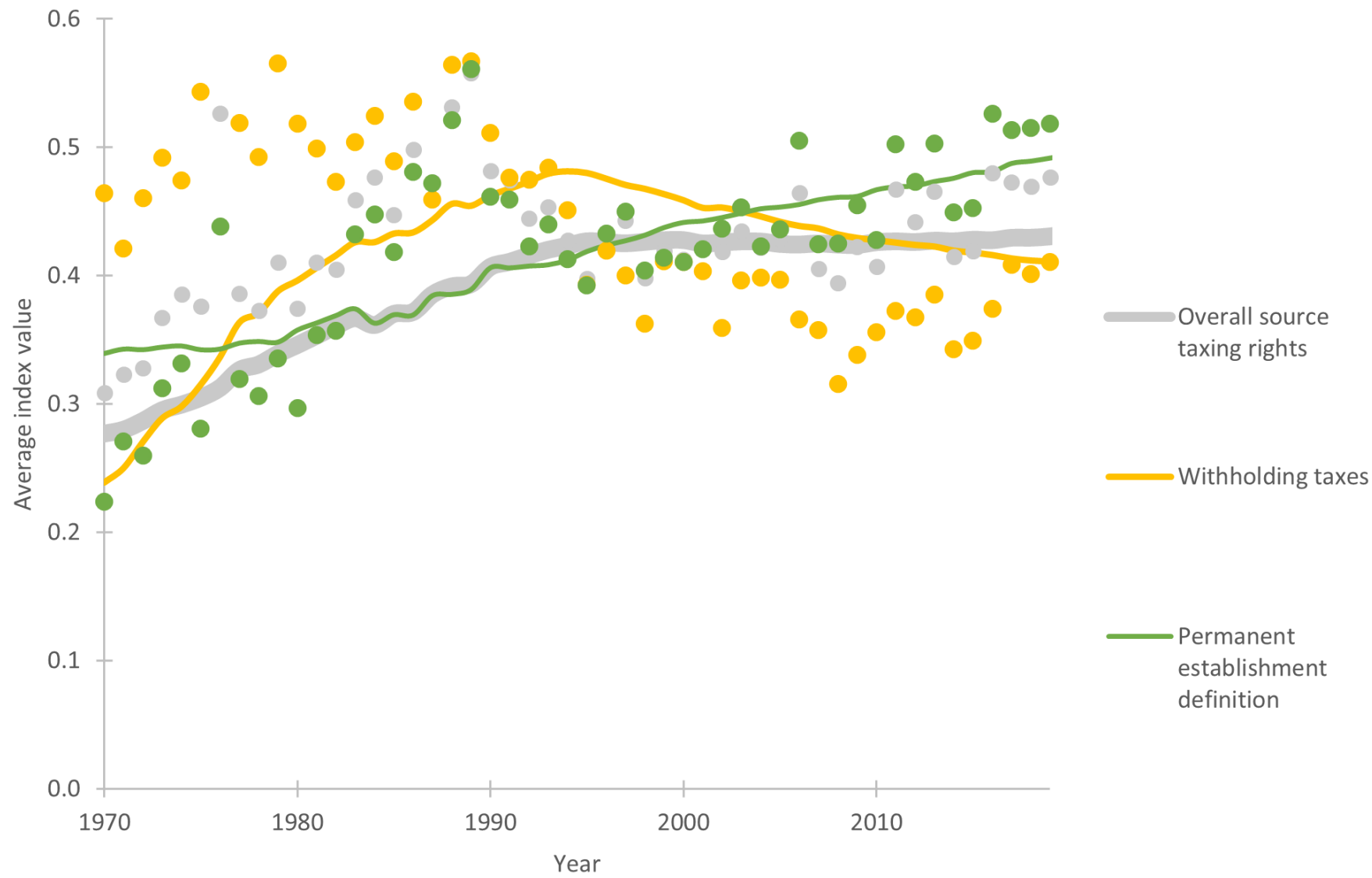

Source: Tax Treaties Explorer dataset, https://www.treaties.tax/.

Note: The dataset's "Index of source taxing rights" is a high-level overview of taxing rights, comprising the averages of the PE definition, WHT rate, and "Other provisions" indexes. Solid lines designate all treaties in force at a given time, whereas individual dots designate the average index values for treaties signed in each year. 
$>>>$

FIG URE 2 - Evolution of Main WHT Rates within Treaties in Force, 1970-2019

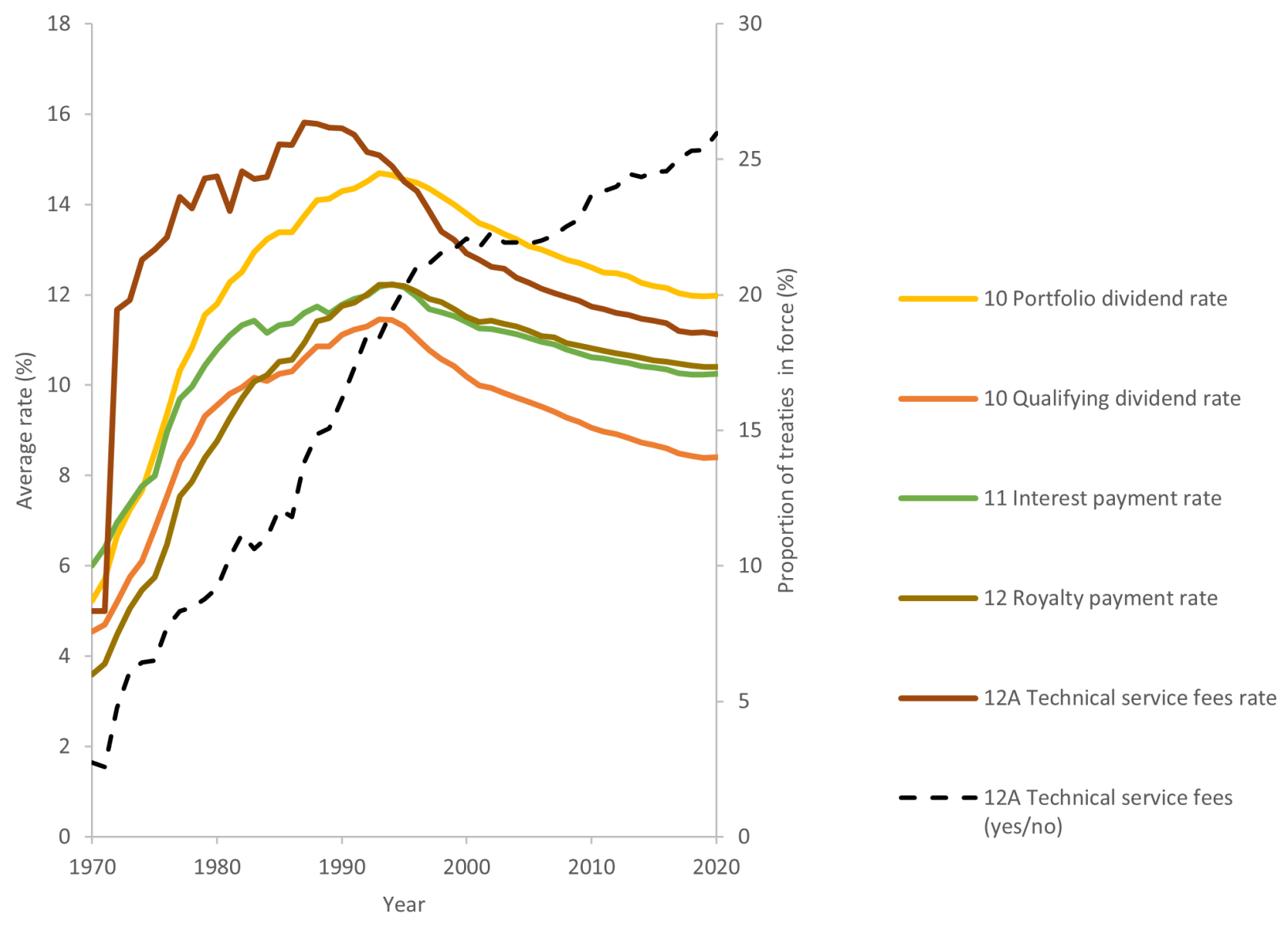

Source: Tax Treaties Explorer dataset, https://www.treaties.tax/.

Note: Lines designate averages of all treaties in force at a given time. Legend designates treaty article numbers pertaining to respective withholding tax (WHT) rates. 
$>>>$

FIG URE 3 - Evolution of Various PE Provisions within Treaties in Force, 1970-2019

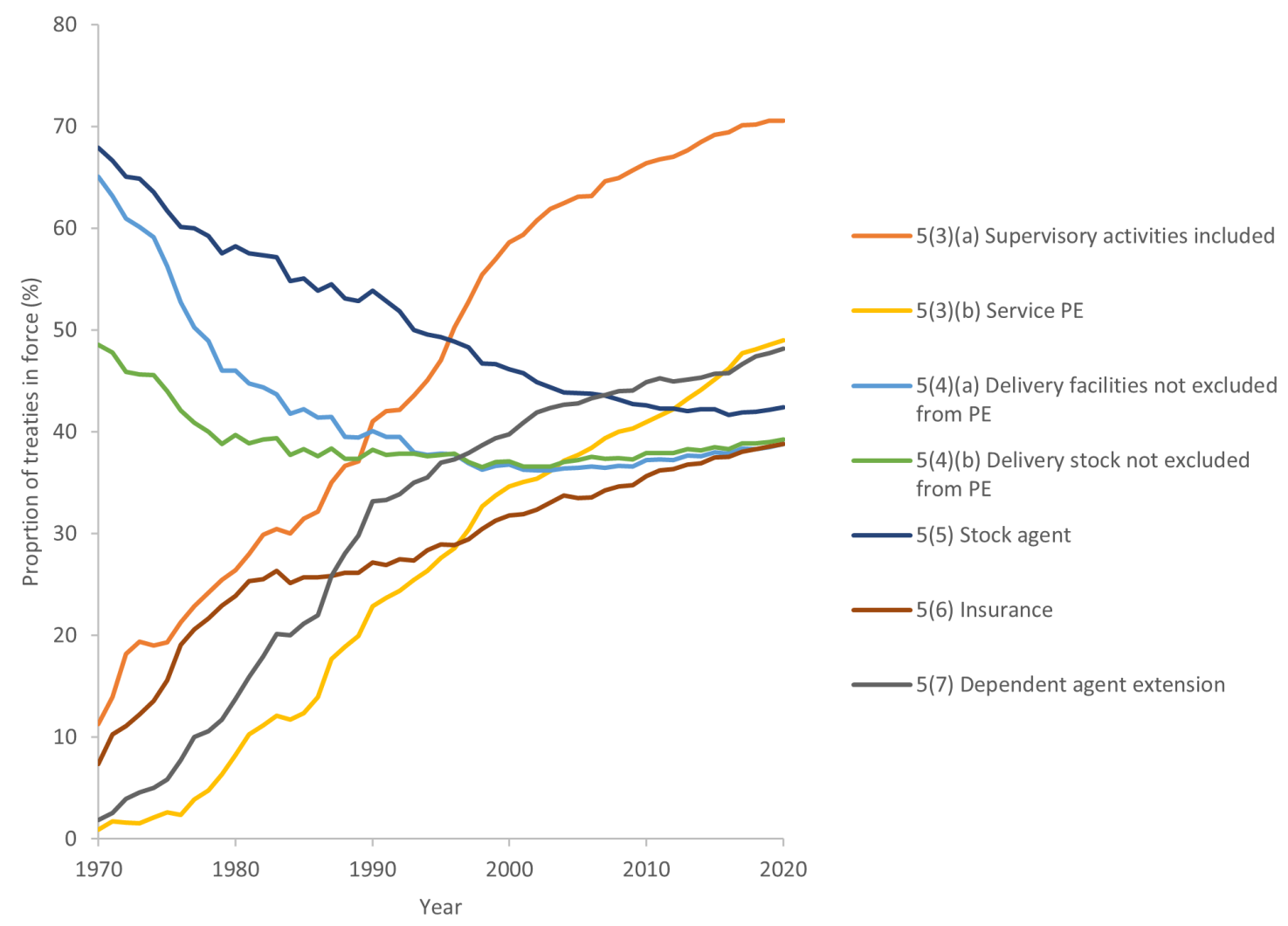

Source: Tax Treaties Explorer dataset, https://www.treaties.taxl.

Note: Lines designate averages of all treaties in force at a given time. Legend designates treaty article and paragraph numbers pertaining to respective components of the permanent establishment (PE) definition.

\section{$\gg$ IMPACT OF MULTILATERAL NEGOTIATIONS ON BILATERAL TREATIES}

\section{$\gg$ CHANGES TO THE MODEL CONVENTIONS}

Since its first publication in 1980 , the UN model has provided a template for treaties with expanded source taxing rights, and its evolution in subsequent editions has continued in this direction. In many instances, however, changes to the UN and OECD models formalize innovations that had already become prevalent in negotiation practice. Indeed, tax treaty provisions can diffuse quite widely even when they are absent from the UN and OECD models. Examples in the dataset include the following:

- $\quad$ Article 12A (providing for WHTs on technical service fees) was adopted in the UN model in 2017, but it was becoming increasingly popular before this point, albeit in a minority of treaties. Aside from bilateral treaties, it could be found in the Caribbean Community (CARICOM) multilateral treaty of 1994, the Southern African Development Community (SADC) model treaty of 2011, and the ATAF model of 2016 before its inclusion in the UN model.

- Both the OECD and UN model conventions now include paragraph 13(4), which allows for source taxation of gains from the alienation of shares in companies whose value derives predominantly from immovable assets-a protection against tax avoidance through offshore indirect transfers of assets. Paragraph 13(4) was present in the first UN model published in 1980 but was only introduced into the OECD model in 2003.

- The two multilateral models only acquired general Entitlement to Benefits (antiabuse) clauses in 2017, although some countries have pursued such clauses in their treaties for many years.

Figure 4 shows the evolution of these three provisions within the dataset's sample of treaties. As before, the proportion of treaties signed in a given year that include each provision is shown as a dot, while the proportion of treaties in force is shown as a line. Each of the three provisions 
increased in prevalence over the past four decades, even before its adoption in model treaties. In the case of Articles $12 \mathrm{~A}$ and 29 , inclusion in a model convention for the first time appears to lead to a significant increase in the proportion of treaties including it. The inclusion of article 13(4) in the OECD model does not appear to change the overall trend, which is unsurprising given that it was already present in the UN model.

The other trend illustrated in Figure 4 is the substantial lag between changes in current negotiating practice and the body of treaties still in force. The proportion of new treaties containing article 13(4) - source capital gains on "land rich" company-is consistently around 20 percentage points higher than those in force. The exponential growth in Entitlement to Benefits clauses is even more pronounced. Despite their inclusion in most of the treaties signed in the past few years, fewer than 10 percent of those in force included such clauses prior to MLI implementation. Keeping unrevised older treaties in force thus risks revenue losses both through exposure to abuse and through the absence of provisions securing source taxing rights that have now become commonplace. As the
African Tax Administration Forum argues, "Africa is still beset by serious issues such as . . . tax treaties with no appropriate tax allocation rights between source and residence taxation and thus susceptible to abuse" (ATAF 2019, 15).

The growing gap between old treaties and present-day needs can be understood as a result of several interlinked processes. At the global level, changes to the models are based on iterative learning, evolving economic activity, the emergence of new tax planning practices, and some normative shifts. At the country level, they may respond to changing patterns of economic relations, modifications to tax systems (especially the introduction of new taxes), stronger negotiating capacity, changing political priorities, and lessons learned from the application of treaties. There is ample evidence that past negotiations by lower-income countries have suffered from capacity deficits, lack of preparation, and pressure from political actors who did not take into account the full impact of treaties on future revenues (Hearson 2021; Irish 1974; Mutava 2019).

\section{$>>>$}

\section{FI G U R 4 - Presence of New Model Treaty Provisions (Excluding Changes due to MLI), 1980-2019}

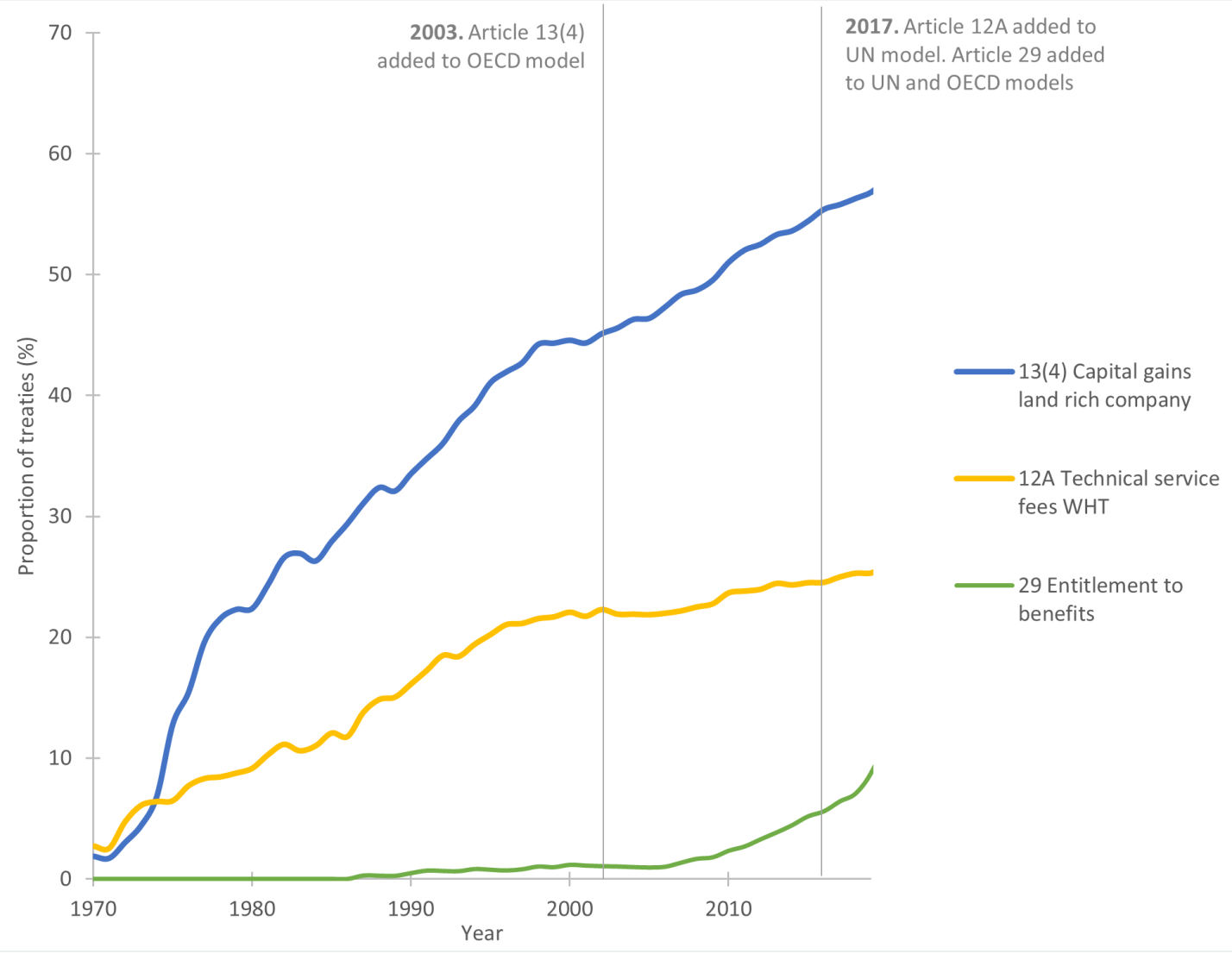

Source: Tax Treaties Explorer dataset, https://www.treaties.taxl.

Note: Solid lines designate all treaties in force at a given time, whereas individual dots designate the average index values for treaties signed in each year. BEPS = base erosion and profit shifting; MLI = OECD/G-20 Multilateral Instrument to Implement Treaty-Related Aspects of BEPS; OECD = Organisation for Economic Co-operation and Development; UN = United Nations; WHT = withholding tax. 


\section{\> THE MULTILATERAL INSTRUMENT}

In 2017, members of the OECD/G-20 IF on BEPS tried a new approach to make treaty norms filter through more quickly into treaties already in force. The Multilateral Instrument to Implement Treaty-Related Aspects of BEPS ("MLI") offers the potential to make wide-ranging changes to tax treaties, including in four provisions measured in the dataset.

Figure 5 shows the impact of the MLI on all treaties covered by the dataset regarding four provisions that are captured in the dataset. Figure 6 shows the impact specifically on the treaties of five lower-income countries that have already ratified the $\mathrm{MLI}$. For three of these provisions, the MLI largely consolidates changes in the treaty network that have been under way for decades. This is especially the case because countries choose which of their treaties are to be covered by the MLI and can also opt out of many of its provisions.
Unless countries' MLI reservations reflect changes to their treaty policy, its effects are limited. For Articles 13(4) and 5(7), the $\mathrm{MLI}$ reflects a longstanding preference on the part of lowerincome countries that is already found in most of their treaties. Nonetheless, the MLI has added Article 13(4) to around 10 percent of the treaties in force in the countries featured in Figure 6. Conversely, few LMICs have opted into mandatory binding arbitration, meaning that it has little impact here.

The standout difference is the Entitlement to Benefits article, which treaties amended by the MLI must include in some form. Here, the MLI has amended the body of treaties in force almost overnight, increasing the prevalence of this article to a level comparable with that in newly signed treaties. Among the five sample countries, the MLI has already increased the prevalence of this article from 14 percent to 61 percent of the treaties in force.

\section{$>>>$}

\section{F I G URE 5 - Dataset Treaties in Force: Impact of the MLI, 1970-2019}

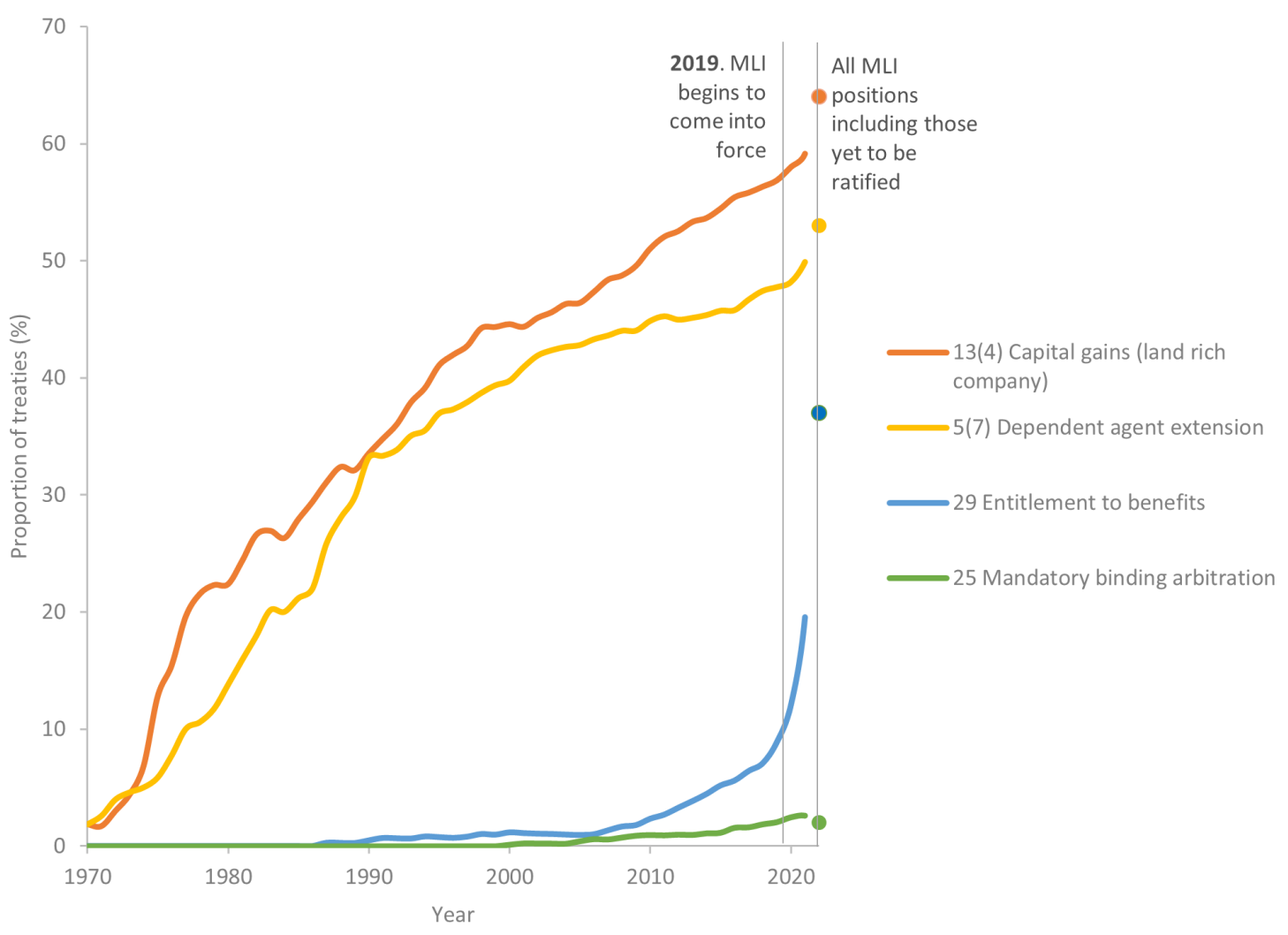

Source: Tax Treaties Explorer dataset, https://www.treaties.taxl.

Note: Solid lines designate all treaties in force at a given time, whereas the four individual dots designate the impact of the MLI on current treaties if all countries' published positions were to be ratified and come into force. BEPS = base erosion and profit shifting; MLI =OECD/G-20 Multilateral Instrument to Implement Treaty-Related Aspects of BEPS; OECD = Organisation for Economic Co-operation and Development; UN = United Nations; $W H T=$ withholding tax. 
$>>>$

F I G U R E 6 - Impact of the MLI, 1970-2019, on Five Ratifying Lower-Income Countries: Burkina Faso, Arab Republic of Egypt, India, Indonesia, and Pakistan

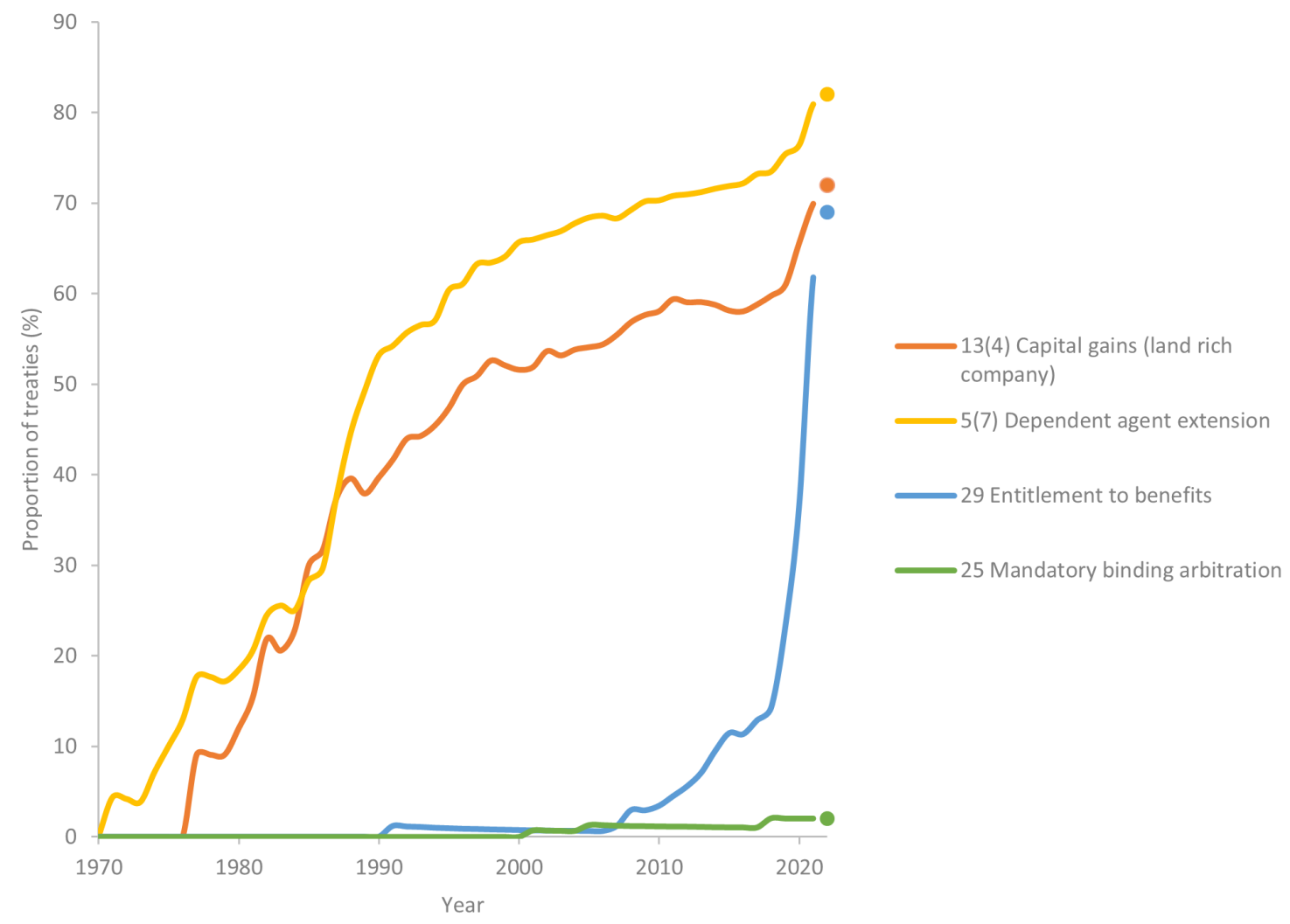

Source: Tax Treaties Explorer dataset, https://www.treaties.taxl.

Note: Solid lines designate all treaties in force at a given time, whereas the four individual dots designate the impact of the MLI on current treaties if all countries' published positions were to be ratified and come into force. BEPS = base erosion and profit shifting; MLI = OECD/G-20 Multilateral Instrument to Implement Treaty-Related Aspects of BEPS; OECD = Organisation for Economic Co-operation and Development; UN = United Nations; $W H T=$ withholding tax .

\section{$\gg>$ INTERNATIONAL PRACTICE ON PE THRESHOLDS}

While some suggest that lower-income countries would be best served by radically overhauling or abandoning the tax treaty system altogether (Dagan 2000; Paolini et al. 2016; Pistone 2010; Shepherd 2013), for many countries the pragmatic response will be to identify the treaties of most concern and seek to renegotiate them in line with the best precedent currently available. For example, an IMF technical assistance report studied Mongolia's tax treaty network and made recommendations for action. It concluded, regarding double tax agreements (DTAs), "In the current situation, only a few DTAs can be considered potentially harmful as they insufficiently protect the Mongolian tax base . . . Mongolia should take a more differentiated approach toward repairing its DTA network by selectively (re-) negotiating and/or amending its current DTAs" (Michielse 2012, 5).
The Mongolian government eventually terminated four treaties, apparently because it did not receive satisfactory responses to its requests to renegotiate. These were with Kuwait, Luxembourg, the Netherlands, and the United Arab Emirates.

As the IMF report makes clear, however, certain aspects of Mongolia's other treaties should give cause for concern. For example, several treaties are "unusual[ly] generous compared with international standards" because they set minimum periods of time for construction and service PEs in excess of 12 months. Bearing in mind the domestic law's thresholds of 6 months and 3 months, respectively, the IMF report recommends that the construction PE threshold "should not be less than the time period used in [domestic law] (i.e., 6 months), and try to limit this time period to 12 months (i.e., the internationally acceptable time period)" while the service PE should always be included in treaties and "should not be extended to more than 6 months (to comply with international 
practice)" (Michielse 2012, 8).

Analysis of the new Tax Treaties Explorer dataset confirms these notions of international practice. It is indeed exceptionally rare to find thresholds in excess of 12 months in any treaties in force (Figure 7). For construction PE, the mode is a 6-month threshold, although it is 12 months in around a quarter of treaties. For service PE, it is rare to include a threshold longer than 6 months. That said, only around half of treaties in force have a service PE provision at all.

$>>$

FIG URE 5 - Construction and Service PE Thresholds within Treaties in Force, 2020

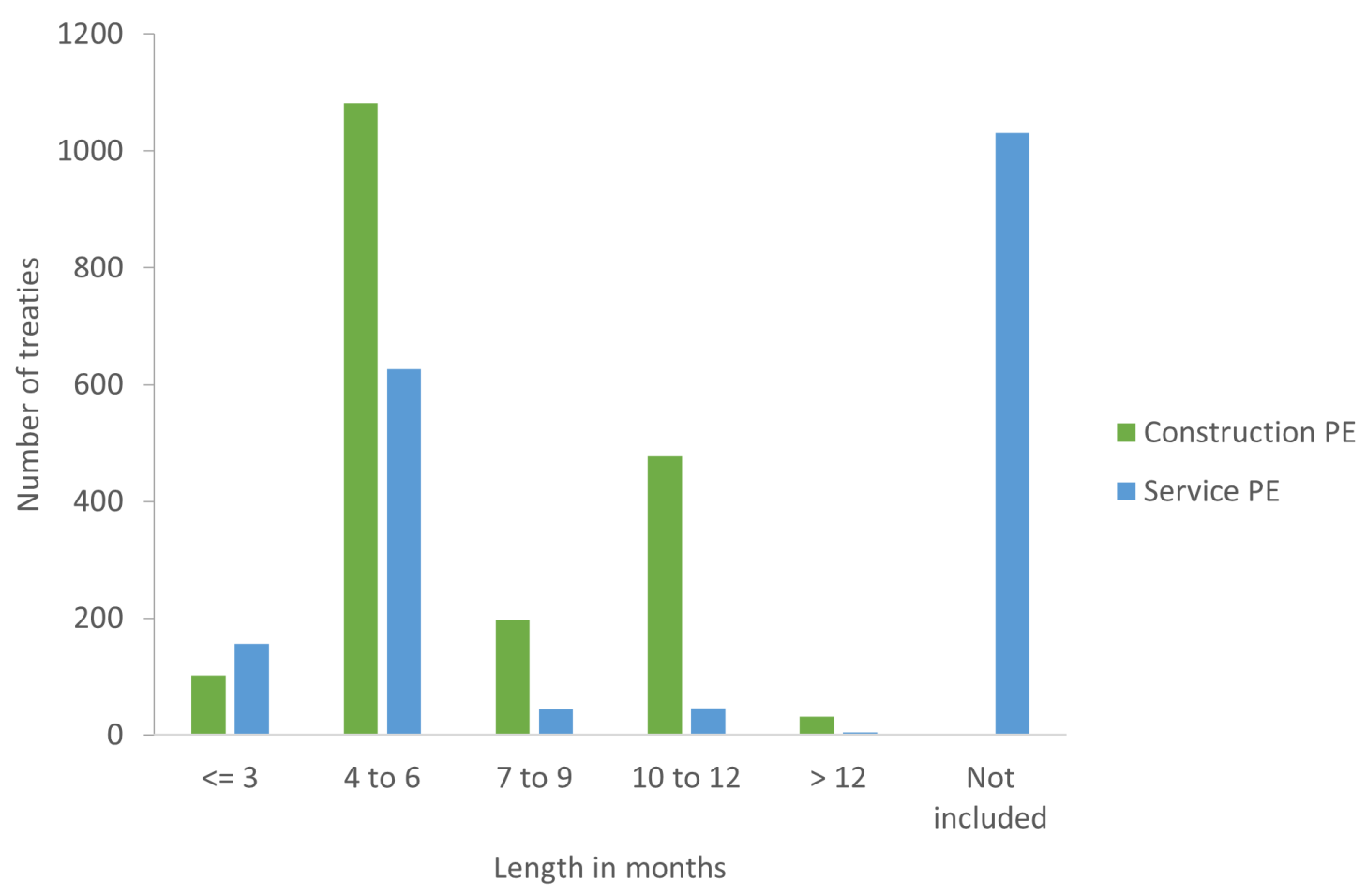

Source: Tax Treaties Explorer dataset, https://www.treaties.taxl.

Note: The permanent establishment (PE) thresholds shown are the minimum periods of time for construction and service PEs, respectively. "Not included" refers to the number of treaties that contain no such provisions. 
Figure 8 adds an important piece of context to this. While the average thresholds for construction and service PE have stabilized at 8 months and 6 months, respectively, only half of treaties currently in force include the service PE provision, but it is becoming much more common. Since the mid-2000s, twothirds of new treaties in the dataset have included a service PE provision.

Mongolia's treaty with China is singled out in the IMF report because both its PE thresholds are unusually long, at 18 months (Michielse 2012). The dataset shows that this threshold is also unusually high for China: it has 45 treaties in force in the dataset, and of these only the treaties with Mongolia, Sudan, and Ukraine have 18-month thresholds. (In Sudan's case, only the construction PE threshold is 18 months.) These three treaties are all more than 20 years old.
The IMF report notes that although Mongolian law considers a person who habitually maintains a stock of goods or merchandise from which they regularly deliver goods and merchandise on behalf of a foreign enterprise to constitute a $\mathrm{PE}$, most of its tax treaties do not. It would be worth noting here that the stock agent provision is the only source-favoring $\mathrm{PE}$ provision to have consistently declined in prevalence over the past 50 years (Figure 3 ).

\section{$>>>$}

\section{FIG U RE 8 - Evolution of Construction and Service PE Provisions, 1970-2019}

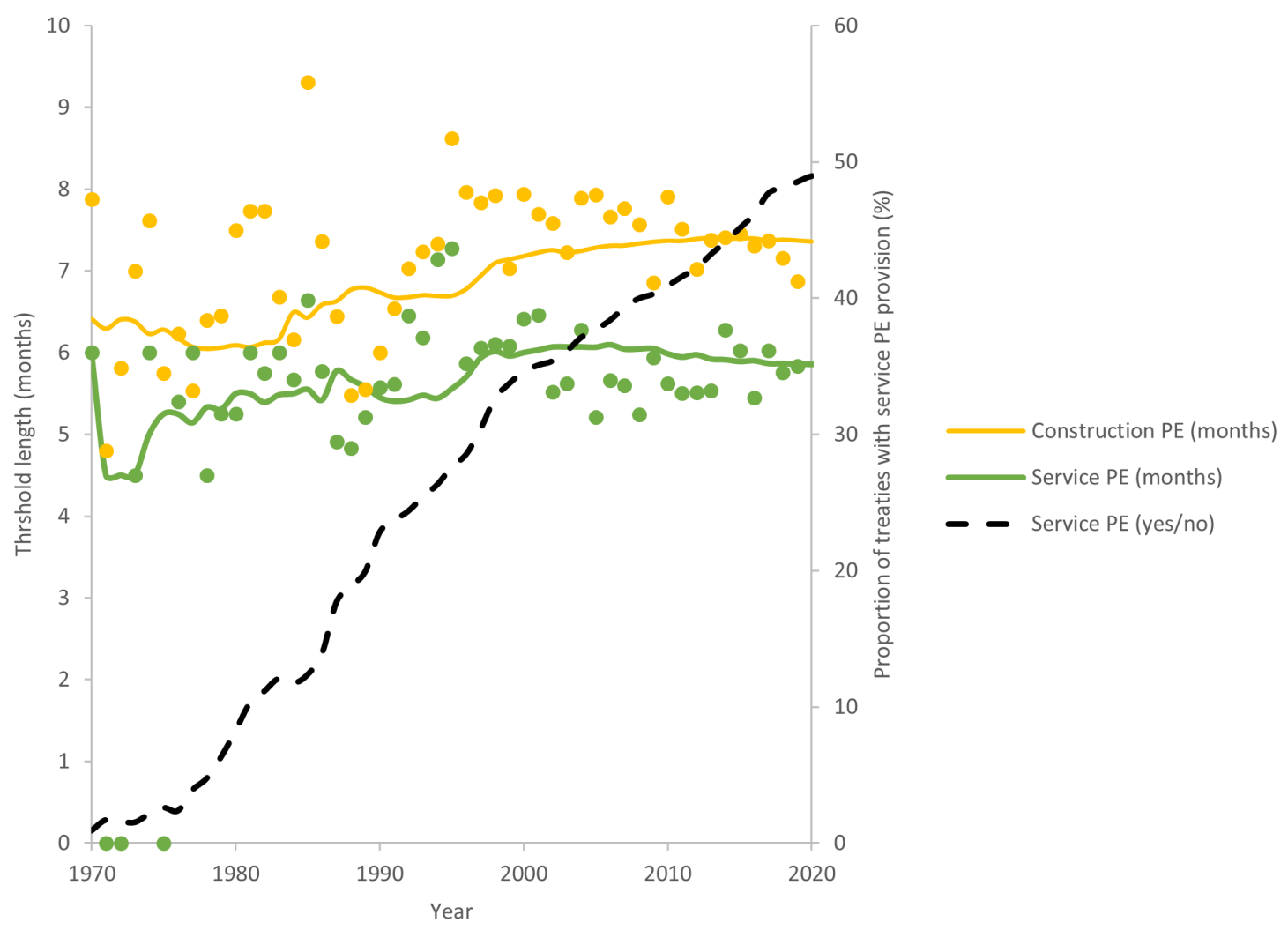

Source: Tax Treaties Explorer dataset, https://www.treaties.taxl.

Note: The left axis indicator refers to minimum periods for construction and service permanent establishment (PE) thresholds, respectively. Solid lines designate all treaties in force at a given time, whereas individual dots designate the average index values for treaties signed in each year. The dashed line (measured by the right axis) indicates the proportion of treaties in force that include a service PE provision. 


\section{$\gg$ P EXPERIENCE RENEGOTIATIONS}

WITH

The Tax Treaty Explorer dataset includes numerous examples of renegotiations, through amending instruments as well as terminations and replacements of treaties altogether. In Figure 9, all renegotiations by lower-income countries are plotted showing the value of the index of overall source taxing rights: the value before renegotiation is on the $x$-axis and following it on the y-axis. The solid line is at 45 degrees, indicating values that are the same on both axes. Treaties above (below) the line have a higher (lower) index value following the renegotiation, indicating that the renegotiation strengthened (weakened) source taxing rights.
The chart shows that all renegotiations that began from a treaty whose index value was below 0.4 -especially restrictive treaties-led to an expansion of source taxing rights. Conversely, when treaties whose index value was above 0.7 were renegotiated, the result was a weakening of source taxing rights. Most renegotiations are, however, clustered around the diagonal line, suggesting only a modest change in the overall balance of taxing rights that may be below the sensitivity of the index approach.

\section{$>>>$}

F I G U R E 9 - Impact on the Overall Source Taxing Rights from Lower-Income Countries' Treaty Renegotiations since 2010

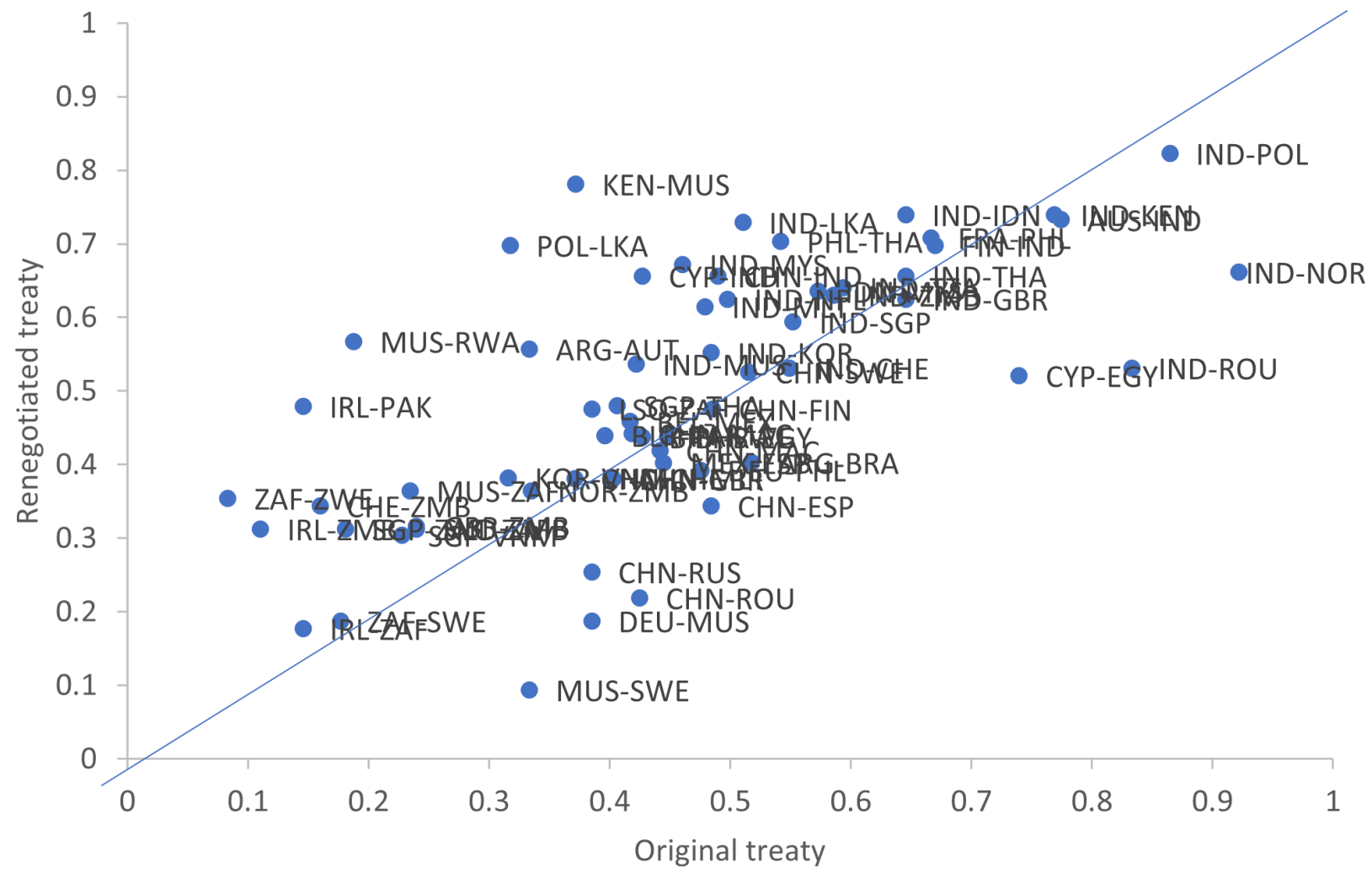

Source: Tax Treaties Explorer dataset, https://www.treaties.taxl.

Note: The dataset's index of overall source taxing rights (on a 0-1 scale) provides a high-level overview of taxing rights, comprising the averages of the permanent establishment (PE) definition, withholding tax (WHT) rate, and "Other provisions" indexes. "Lower-income" countries are those falling within the low- and lower-middle-income categories as defined by the World Bank. Countries are labeled using ISO alpha-3 codes. 
The two most radical renegotiations in a source-based direction were those by Kenya and Rwanda with Mauritius. Alongside the terminated treaties with Senegal and Zambia, these were among the most residence-based of all Mauritius's treaties. Table 3 summarizes each, and Annex A provides a detailed breakdown of the treaties. The two new treaties are among the most source-based, and it should be noted that Rwanda's treaty was terminated before these renegotiations, while Kenya's had been struck down by its High Court. Mauritius conceded significantly expanded PE definitions in both cases, including a halving of the construction and service PE thresholds. Both countries also obtained WHTs on technical service fees, a provision found in only four other treaties concluded by Mauritius.
In terms of WHTs, Rwanda's treaty is a major improvement from its predecessor, which had prohibited WHTs across the board. Kenya also obtained taxing rights over ships in international traffic, capital gains, and other income, as well as an Entitlement to Benefits article. Given the new treaties' content and Mauritius's position as a conduit jurisdiction responsible for significant revenue loss (Beer and Loeprick 2021), these terminations and renegotiations reflect a prioritization based on high costs and risks as well as potential for improvement. Among capital importers from Mauritius, only the Republic of Congo has a more residence-based treaty still in force (also shown in Annex A). ${ }^{8}$

$>>$

\section{TA B LE 3 - Selected Treaties with Mauritius}

COUNTRY A DATE OF SIGNATURE

\begin{tabular}{|c|c|c|c|c|c|c|}
\hline \multirow{2}{*}{ Kenya } & 2012 & Not in Force & 0.37 & 0.30 & 0.44 & 0.38 \\
\hline & 2019 & Not in Force & 0.78 & 0.50 & 0.97 & 0.88 \\
\hline \multirow{2}{*}{ Rwanda } & 2001 & Terminated & 0.19 & 0.00 & 0.31 & 0.25 \\
\hline & 2013 & In Force & 0.57 & 0.48 & 0.84 & 0.38 \\
\hline Senegal & 2002 & Terminated & 0.23 & 0.00 & 0.45 & 0.25 \\
\hline Zambia & 2011 & Terminated & 0.22 & 0.29 & 0.20 & 0.17 \\
\hline Congo, Rep. & 2010 & In Force & 0.18 & 0.09 & 0.31 & 0.13 \\
\hline
\end{tabular}

Source: Tax Treaties Explorer dataset, https://www.treaties.tax/.

Note: $P E=$ permanent establishment; $W H T=$ withholding tax.

Two of the renegotiations that impose greater restrictions on taxing rights are India's, with Norway in 2011 and Romania in 2013. These appear to reflect a change in India's negotiating policy around 2000, toward a less source-based position: WHT rates have fallen dramatically, and several sourcebased provisions-including the UN limited force of attraction provision in Article 7 (i) and source taxation of shipping in Article 8-are now rarely found in new treaties signed by India, except a few with LMICs.

In contrast, both renegotiations resulted in the removal of taxing rights over indirect transfers of assets through paragraph 13(4) of the model treaties, which is found in the large majority of India's new treaties since 2000. Instead, the renegotiated treaty with Romania accommodated India's apparent priority of expanded taxing rights over gains from the sales of Indian companies under a provision similar to paragraph 13(5) of the UN model, which was already found in the Norway treaty. Notably, both these renegotiations also introduced an Entitlement to Benefits clause, which has been found consistently in India's new treaties for the past decade.

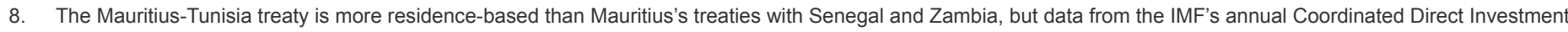
Survey (2000) indicate that Tunisia is a net exporter of capital to Mauritius. 


\section{$\gg$ NEW NEGOTIATING PARTNERS}

Figure 10 shows new treaties signed by lower-income countries with some of the most prolific negotiators in recent years. The top panel shows India and China's treaties, illustrating that, since 2010, the mid 2000s, the two have diverged considerably, India now concluding more sourcebased treaties, and China more residence-based treaties. Decomposing this further shows that the overall WHT settlements for the two countries are similar, whereas India's recent treaties have much more expansive PE definitions than do China's.
The second panel illustrates treaties with several gulf states, which now have wide treaty networks with lowerincome countries, reflecting the interests of sovereign wealth funds, airlines, and the oil industry. Notably, many of these countries do not tax income and so the risk of double taxation may be especially low. The finding here is that treaties' content is much more varied overall, with some treaties scoring low in the index. All these treaties have relatively low or zero WHT rates, but their PE definitions are much more heterogeneous.

$>>>$

\section{F I G U R E 10 - Index of Source Taxing Rights for New Treaties Signed by Lower-Income Countries and Selected Countries}

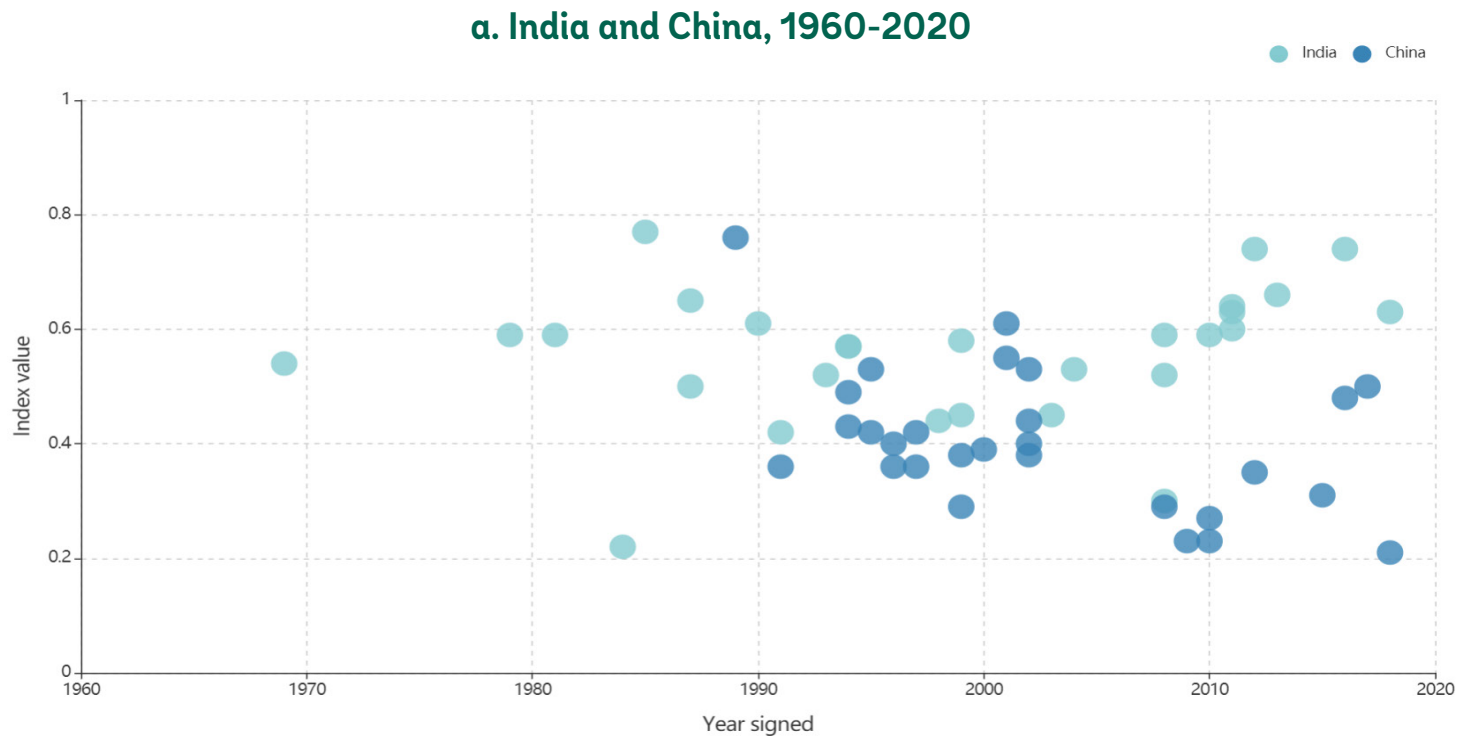

\section{b. Selected Persian Gulf States, 1990-2020}

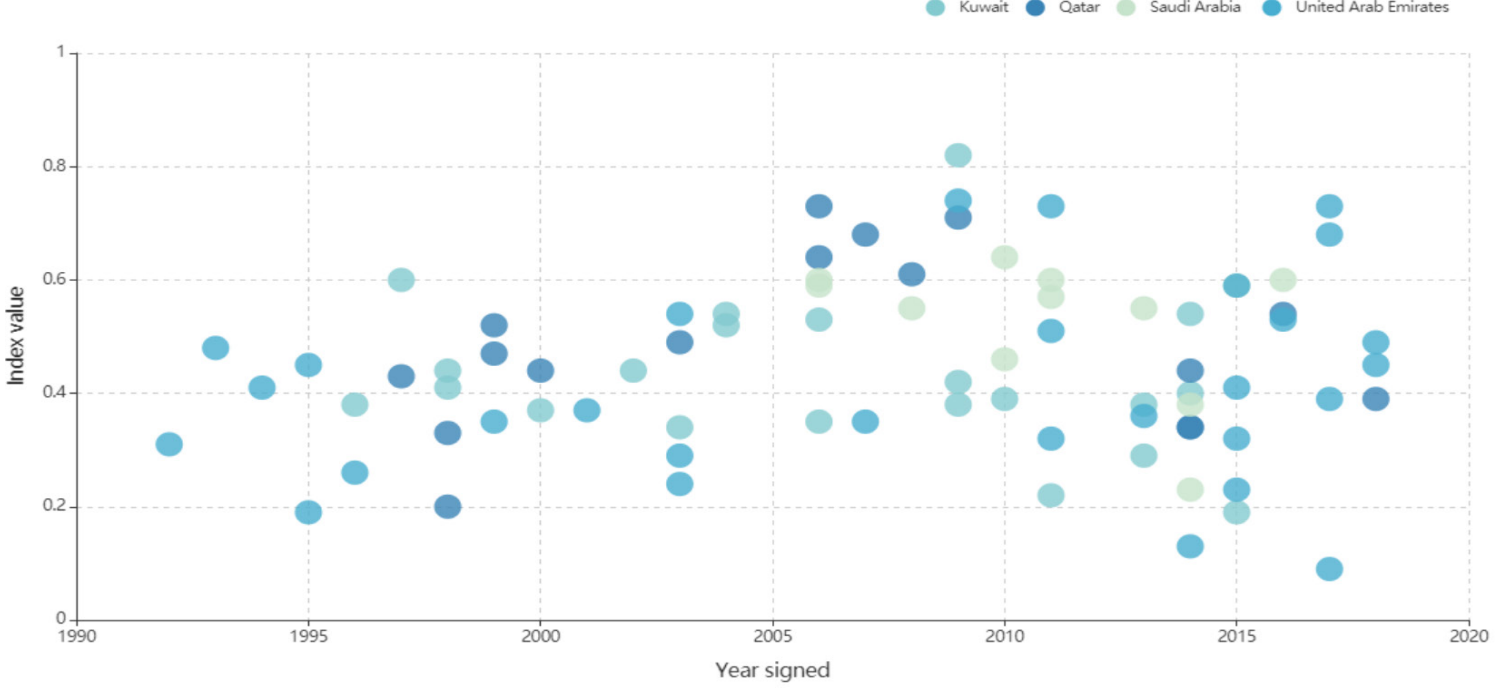

Source: Tax Treaties Explorer, https://tinyurl.com/yjlvvakg (panel a) and https://tinyurl.com/yidj6z9x (panel b).

Note: The scatterplot represents data from the index of overall source taxing rights, which covers all coded clauses that relate to the balance of taxing rights, comprising the averages of the permanent establishment (PE) definition, withholding tax (WHT) rate, and "Other provisions" indexes. It gives a high-level overview of the treaty. Each dot designates an individual treaty between one of the specified countries with a lowerincome country that was signed in a given year. "Lower-income" countries are those falling within the low- and lower-middle-income categories as defined by the World Bank. 


\section{$\gg$ REPLICATION STUDY: TAX TREATIES AND FDI}

As noted earlier, much academic literature is animated by the question of how tax treaties affect business decisions. From a policy perspective, a key question is whether a new treaty can be expected to increase the stock of investment between the treaty partners. The answer, we suggested, depends on the terms of the treaty and the identity of the treaty partners, as well as on the two countries' existing treaty networks and the characteristics of their tax systems.

Here we examine the first part of the puzzle: how do the terms of a treaty shape its impact on FDI? Given the increasing sophistication of the literature on this topic, our aim in what follows is simply to demonstrate how the Tax Treaties Explorer dataset can help build on existing findings by replicating a previous study and replacing the binary independent variable measuring the presence of a treaty with variables based on the dataset. Our proof-of-concept study suggests that only lower treaty WHT rates are positively associated with FDI stocks. This finding should be tested using more recent innovations in data and methodology.

Our starting point is a 10 -year-old study that finds that tax treaties positively affect investment flows (Barthel, Busse, and Neumayer 2009). We chose this study because its sample overlaps well with treaties in the dataset, its model is straightforward to replicate, and the authors have made the data to do so available online. Briefly, the original study is a dyadic panel data model, using dyadic fixed effects, that examines the impact of tax treaties on bilateral FDI stocks. The authors conclude that a tax treaty between two countries increases the stock of FDI by approximately 30 percent and that treaties' effect on the stock of FDI increases with age. This is a large effect size and may be prone to overestimation because it does not account for treaty shopping.

Our analysis proceeds in two steps. First, we recreate the model from the study of Barthel, Busse, and Neumayer (2009), using their replication data but inserting revised data on effective treaties, drawn from the Tax Treaties Explorer dataset. Second, with respect to those dyads in which a treaty is in force, we examine how the treaty's content increases or reduces its impact on FDI to determine which provisions that favor source state taxation can be included in a treaty without affecting FDI stocks.

\section{$\gg$ REPLICATING THE FDI IMPACT MODEL WITH NEW DATA}

In the first stage of the analysis, the impact of a treaty on FDI is captured as a dummy variable indicating that a tax treaty is effective. During the period of 1978 to 2003, our sample includes 1,814 dyads and 547 tax treaties.

Our approach makes three small changes from the baseline of Barthel, Busse, and Neumayer (2009). First, in common with that study, we take the year of effectiveness as the start of the treaty's effect on FDI. In contrast to it, however, where the treaty becomes effective retrospectively - that is, the effective date is earlier than the signed date-we use the date of signature. Our rationale here is that any investors influenced by the presence of a treaty may be unwilling to commit capital until it has been signed. Second, we account for treaty terminations, setting the value of the dummy to zero in years after a treaty ceases to be effective. Finally, where there is a disagreement between the Barthel, Busse, and Neumayer (2009) dataset and the Tax Treaties Explorer dataset, we use the latter.

We report the results of three models in Table 4. The full methodology and data sources are outlined by Barthel, Busse, and Neumayer (2009), but, in summary, the first two models are a standard panel regression using dyadic fixedeffects, where each dyad of countries has its own intercept and for which we use standard errors clustered on dyads. The dynamic model differs from the static in that we include the lagged value of the dependent variable, which reduces any overestimation of results due to the dynamic effect of FDI (Egger and Merlo 2007). We also replicate a third model from Barthel, Busse, and Neumayer (2009), based on the Arellano and Bond (1991) generalized method of moments (GMM) estimator, which is used to correct any presence of Nickell (1981) bias that may arise in the dynamic estimator and also to take into account any possible endogeneity. The number of lagged instruments is restricted to six. Following Barthel, Busse, and Neumayer (2009), the results in column (3) use the age of a treaty instead of the dummy. 
TA B LE 4 - Estimation Results for Pure Replication

\begin{tabular}{|c|c|c|c|}
\hline & $\begin{array}{c}(1) \\
\text { FE STATIC }\end{array}$ & $\begin{array}{c}\text { (2) } \\
\text { FE DYNAMIC }\end{array}$ & $\begin{array}{c}\text { (3) } \\
\text { ARELLANO-BOND GMM }\end{array}$ \\
\hline DTT (dummy) (t) & $\begin{array}{l}0.386^{* * *} \\
(0.088)\end{array}$ & $\begin{array}{l}0.096^{* *} \\
(0.038)\end{array}$ & \\
\hline DTT Age (t) & & & $\begin{array}{l}0.027^{* * *} \\
(0.009)\end{array}$ \\
\hline $\mathrm{BIT}(\mathrm{t})$ & $\begin{array}{c}0.496^{* * *} \\
(0.089)\end{array}$ & $\begin{array}{l}0.107^{* * *} \\
(0.029)\end{array}$ & \\
\hline BIT Age (t) & & & $\begin{array}{l}-0.000 \\
(0.009)\end{array}$ \\
\hline (In) FDI Stock (t-1) & & $\begin{array}{c}0.760^{* * *} \\
(0.030)\end{array}$ & $\begin{array}{l}0.715^{* * *} \\
(0.052)\end{array}$ \\
\hline$(\ln ) \mathrm{GDP}(\mathrm{t})$ & $\begin{array}{l}0.274^{* * *} \\
(0.038)\end{array}$ & $\begin{array}{c}0.089^{* * *} \\
(0.015)\end{array}$ & $\begin{array}{c}0.064^{* * *} \\
(0.021)\end{array}$ \\
\hline (In) GDP p.c. (t) & $\begin{array}{c}0.018 \\
(0.089)\end{array}$ & $\begin{array}{l}-0.024 \\
(0.029)\end{array}$ & $\begin{array}{l}0.058 \\
(0.051)\end{array}$ \\
\hline (In) Inflation (t) & $\begin{array}{l}-0.018^{* * *} \\
(0.005)\end{array}$ & $\begin{array}{c}-0.007^{* * *} \\
(0.002)\end{array}$ & $\begin{array}{l}-0.002 \\
(0.002)\end{array}$ \\
\hline Trade Openness ( $\mathrm{t}$ ) & $\begin{array}{c}0.002^{* * *} \\
(0.000)\end{array}$ & $\begin{array}{l}0.001^{* * *} \\
(0.000)\end{array}$ & $\begin{array}{l}0.001^{* *} \\
(0.000)\end{array}$ \\
\hline Regional Trade Agreement ( $\mathrm{t}$ ) & $\begin{array}{l}0.473^{* * *} \\
(0.134)\end{array}$ & $\begin{array}{c}0.098^{* * *} \\
(0.037)\end{array}$ & $\begin{array}{c}0.083 \\
(0.054)\end{array}$ \\
\hline Observations & 20,762 & 18,019 & 15,859 \\
\hline R-Squared & 0.182 & 0.643 & \\
\hline Number of Dyads & 1,814 & 1,671 & 1,560 \\
\hline AR2 (p-value) & & & 0.516 \\
\hline
\end{tabular}

Source: Tax Treaties Explorer dataset, $\underline{\text { https://www.treaties.tax/. }}$

Note: Robust standard errors in parentheses. BIT = bilateral investment treaties; DTT = double taxation treaty; FDI = foreign direct investment; $F E$ = fixed effects; $G M M=$ generalized method of moments; p.c. = per capita.

The results are consistent with those presented in Barthel et al. (2010), with the coefficients for the presence of a tax treaty in all three models positively and significantly associated with higher FDI stocks. The coefficients translate into effect sizes as follows: having a tax treaty in effect increases the stock of FDI in a dyad by 47 percent in the static model, or around 20 percent over the long term in the dynamic model. In the original paper, these figures were both around 30 percent. $^{9}$

\section{$\gg$ APPLYING DATASET INDEXES TO DYADS WITH TREATIES IN FORCE}

Our next step is to replace the binary tax treaty variable with the indexes discussed earlier in the paper. These apply only to dyads for which a tax treaty was effective. It should be noted that value of the indexes for a given dyad may vary as treaties are amended or renegotiated. In Table 5, columns 4-6 show the results for the same three types of model as in the pure replication, but the main independent variable is now the index of overall source taxing rights. Columns $7-9$ show the partial effects of the three subindexes that make up the overall index: withholding tax rates ("WHT rates"), permanent establishment definition ("PE def"), and other clauses affecting the balance between source and residence taxation ("Other"). Columns 10-12 show the results using the index of similarity to the UN model treaty as the independent variable.

In columns 4 and 5 , the index of overall source taxing rights is negatively and significantly associated with the stock of FDI in both the static and dynamic models, suggesting that greater protection for source taxing rights reduces the stock of FDI. Concretely, switching one treaty clause from the least to most source-based text included in the dataset reduces the stock of FDI by around 2 percent. In columns $7-9$, it is WHT rates that most convincingly affect FDI stocks once we attempt to compensate for overestimation, Nickel bias and endogeneity,

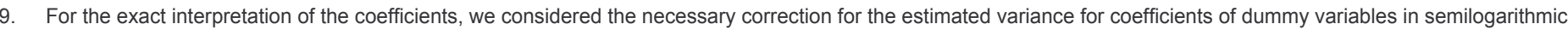
equations, as in Kennedy (1981). 
as they are negatively and significantly associated with FDI stocks in both the dynamic and GMM models. Concretely, in the dynamic fixed effects model, an across-the-board reduction in all types of WHT rate of 1 percentage point would increase the stock of FDI by 2 percent in the short term and by 3.5 percent over the longer term. The effect size is 4 percent in the GMM model.

The limitations of this replication study illustrate the potential for future research using the dataset. To begin with, we replicated a study whose methodology has been superseded in most more-recent publications by the use of microdata or network analysis to account for the impact of treaty shopping. Furthermore, we were only able to use absolute WHT rates in treaties and not the differential between domestic law and the treaty rate; similarly, for other provisions, we could not compare treaties with the domestic law position at the relevant point in time. Our replication study also omits elements of the treaty that are not coded but that studies have shown to have a greater impact on investment, notably "tax sparing" clauses. Finally, we focused only on FDI: it would be interesting to consider how portfolio investment as well as trade in goods, services, and intellectual property might be affected by relevant treaty provisions. 
TA B LE 5 - Estimation Results for Model with Indexes

\begin{tabular}{|c|c|c|c|c|c|c|c|c|c|}
\hline & $\begin{array}{c}(4) \\
\text { FE } \\
\text { STATIC }\end{array}$ & $\begin{array}{c}\text { (5) } \\
\text { FE } \\
\text { DYNAMIC }\end{array}$ & $\begin{array}{c}(6) \\
\text { ARELLANO- } \\
\text { BOND } \\
\text { GMM }\end{array}$ & $\begin{array}{c}(7) \\
\text { FE } \\
\text { STATIC }\end{array}$ & $\begin{array}{c}\text { (8) } \\
\text { FE } \\
\text { DYNAMIC }\end{array}$ & $\begin{array}{c}(9) \\
\text { ARELLANO- } \\
\text { BOND } \\
\text { GMM }\end{array}$ & $\begin{array}{c}\text { (10) } \\
\text { FE } \\
\text { STATIC }\end{array}$ & $\begin{array}{c}(11) \\
\text { FE } \\
\text { DYNAMIC }\end{array}$ & $\begin{array}{c}\text { (12) } \\
\text { ARELLANO- } \\
\text { BOND } \\
\text { GMM }\end{array}$ \\
\hline Source $(t)$ & $\begin{array}{l}-1.321^{* *} \\
(0.647)\end{array}$ & $\begin{array}{c}-0.821^{* * *} \\
(0.226)\end{array}$ & $\begin{array}{c}-0.791 \\
(0.508)\end{array}$ & & & & & & \\
\hline WHT Rates ( $t$ ) & & & & $\begin{array}{l}-0.266 \\
(0.367)\end{array}$ & $\begin{array}{c}-0.517^{* * *} \\
(0.170)\end{array}$ & $\begin{array}{l}-1.836^{* *} \\
(0.830)\end{array}$ & & & \\
\hline$P E(t)$ & & & & $\begin{array}{c}0.430 \\
(0.355)\end{array}$ & $\begin{array}{c}0.015 \\
(0.125)\end{array}$ & $\begin{array}{c}1.797 \\
(1.169)\end{array}$ & & & \\
\hline Other ( $t)$ & & & & $\begin{array}{c}-1.658^{* * *} \\
(0.401)\end{array}$ & $\begin{array}{l}-0.450 \\
(0.306)\end{array}$ & $\begin{array}{l}-1.105 \\
(1.326)\end{array}$ & & & \\
\hline UN (t) & & & & & & & $\begin{array}{l}-1.321^{*} \\
(0.737) \\
\end{array}$ & $\begin{array}{l}-0.453 \\
(0.322) \\
\end{array}$ & $\begin{array}{c}0.358 \\
(0.679) \\
\end{array}$ \\
\hline (In) FDI Stock (t-1) & & $\begin{array}{c}0.589^{* * *} \\
(0.055)\end{array}$ & $\begin{array}{l}0.346^{* * *} \\
(0.072)\end{array}$ & & $\begin{array}{c}0.588^{* * *} \\
(0.055)\end{array}$ & $\begin{array}{l}0.342^{* * *} \\
(0.056)\end{array}$ & & $\begin{array}{c}0.593^{* * *} \\
(0.056)\end{array}$ & $\begin{array}{c}0.369^{* * *} \\
(0.072)\end{array}$ \\
\hline$(\ln )$ GDP $(t)$ & $\begin{array}{c}0.496^{* * *} \\
(0.132)\end{array}$ & $\begin{array}{c}0.248^{* * *} \\
(0.089)\end{array}$ & $\begin{array}{c}0.014 \\
(0.018)\end{array}$ & $\begin{array}{c}0.511^{* * *} \\
(0.131)\end{array}$ & $\begin{array}{c}0.253^{* * *} \\
(0.089)\end{array}$ & $\begin{array}{c}0.015 \\
(0.017)\end{array}$ & $\begin{array}{l}0.511^{* * * *} \\
(0.137)\end{array}$ & $\begin{array}{c}0.245^{* * *} \\
(0.092)\end{array}$ & $\begin{array}{c}0.009 \\
(0.018)\end{array}$ \\
\hline (In) GDP p.c. (t) & $\begin{array}{l}0.766^{* *} \\
(0.347)\end{array}$ & $\begin{array}{c}0.162 \\
(0.172)\end{array}$ & $\begin{array}{l}0.281^{* * *} \\
(0.106)\end{array}$ & $\begin{array}{l}0.716^{* *} \\
(0.345)\end{array}$ & $\begin{array}{c}0.149 \\
(0.170)\end{array}$ & $\begin{array}{l}0.264^{* * *} \\
(0.095)\end{array}$ & $\begin{array}{l}0.735^{* *} \\
(0.359)\end{array}$ & $\begin{array}{c}0.171 \\
(0.180)\end{array}$ & $\begin{array}{c}0.296^{* * *} \\
(0.113)\end{array}$ \\
\hline (In) Inflation (t) & $\begin{array}{l}-0.019 \\
(0.018)\end{array}$ & $\begin{array}{l}-0.013 \\
(0.012)\end{array}$ & $\begin{array}{c}0.181 \\
(0.290)\end{array}$ & $\begin{array}{l}-0.020 \\
(0.018)\end{array}$ & $\begin{array}{l}-0.014 \\
(0.012)\end{array}$ & $\begin{array}{c}0.289 \\
(0.272)\end{array}$ & $\begin{array}{l}-0.017 \\
(0.018)\end{array}$ & $\begin{array}{l}-0.014 \\
(0.012)\end{array}$ & $\begin{array}{c}0.075 \\
(0.292)\end{array}$ \\
\hline Trade Openness ( $t$ ) & $\begin{array}{l}0.005^{*} \\
(0.003)\end{array}$ & $\begin{array}{l}0.003^{* *} \\
(0.002)\end{array}$ & $\begin{array}{l}-0.005 \\
(0.010)\end{array}$ & $\begin{array}{l}0.005^{*} \\
(0.003)\end{array}$ & $\begin{array}{l}0.003^{* *} \\
(0.002)\end{array}$ & $\begin{array}{l}-0.008 \\
(0.009)\end{array}$ & $\begin{array}{l}0.005^{* *} \\
(0.003)\end{array}$ & $\begin{array}{l}0.003^{* *} \\
(0.002)\end{array}$ & $\begin{array}{l}-0.005 \\
(0.011)\end{array}$ \\
\hline $\begin{array}{l}\text { Regional Trade } \\
\text { Agmt ( } t \text { ) }\end{array}$ & $\begin{array}{c}0.174 \\
(0.191)\end{array}$ & $\begin{array}{c}0.011 \\
(0.095)\end{array}$ & $\begin{array}{l}0.004^{*} \\
(0.003)\end{array}$ & $\begin{array}{c}0.176 \\
(0.190)\end{array}$ & $\begin{array}{c}0.015 \\
(0.095)\end{array}$ & $\begin{array}{c}0.003 \\
(0.002)\end{array}$ & $\begin{array}{c}0.172 \\
(0.190)\end{array}$ & $\begin{array}{c}0.010 \\
(0.095)\end{array}$ & $\begin{array}{l}0.005^{*} \\
(0.003)\end{array}$ \\
\hline $\mathrm{BIT}(\mathrm{t})$ & $\begin{array}{c}0.129 \\
(0.103)\end{array}$ & $\begin{array}{c}0.061 \\
(0.063)\end{array}$ & $\begin{array}{l}-0.014 \\
(0.072)\end{array}$ & $\begin{array}{c}0.126 \\
(0.103)\end{array}$ & $\begin{array}{c}0.058 \\
(0.064)\end{array}$ & $\begin{array}{c}0.046 \\
(0.076)\end{array}$ & $\begin{array}{c}0.130 \\
(0.107)\end{array}$ & $\begin{array}{c}0.064 \\
(0.066)\end{array}$ & $\begin{array}{l}-0.009 \\
(0.072)\end{array}$ \\
\hline Observations & 3,263 & 2,792 & 2,335 & 3,262 & 2,792 & 2,335 & 3,202 & 2,741 & 2,289 \\
\hline R-Squared & 0.279 & 0.548 & 0.822 & 0.281 & 0.548 & 0.760 & 0.274 & 0.550 & 0.899 \\
\hline Number of Dyads & 438 & 380 & 349 & 438 & 380 & 349 & 431 & 375 & 345 \\
\hline AR2 (p-value) & & & 0.822 & & & 0.760 & & & 0.899 \\
\hline
\end{tabular}

Source: Tax Treaties Explorer dataset, https://www.treaties.tax/.

Note: Robust standard errors in parentheses. BIT = bilateral investment treaty; $F D I=$ foreign direct investment; $F E=$ fixed effects; $G M M=$ generalized method of moments; p.c. $=$ per capita; UN = United Nations model treaty; WHT = withholding tax. ${ }^{* * *} p<0.01,{ }^{* *} p<0.05,{ }^{*} p<0.1$ 


\section{$\gg \quad$ CONCLUSION}

The new Tax Treaties Explorer dataset is a powerful tool for research by negotiators and policy makers as well as by researchers. In this paper, we have illustrated some of the new insights that can be drawn from these data, in the hope that future research will deepen this analysis. There can be no substitute for a detailed legal study of the wording of tax treaties and their interaction with countries' tax systems. Nonetheless, in the aggregate, stylized findings of the kind we have identified here can inform and empower negotiators from lower-income countries.

The necessity of analyzing the recent treaties signed by a potential negotiating partner is widely recognized in guidance from international organizations. The dataset can assist with this task, but it also points to clearer notions of current international practice at a more general level. Certain clauses that were rarely included in older treaties are now found in most lower-income countries' newly signed agreements as well as in model conventions, such as the following:

- Inclusion of supervisory activities related to construction activities, as well as the services PE clause, in Article 5 of the UN model

- Source taxation of capital gains from sales of shares in "land rich" companies, found in Article 13 of the OECD and UN models since 2003

- Addition of the Entitlement to Benefits article to both models in 2017.
In these and other areas, recent practice should embolden countries to seek stronger safeguarding of source taxation rights in their negotiating positions, as well as provide a compelling rationale to renegotiate older agreements that are no longer consistent with current practice. Although declining WHT rates since the 1990s may give countries cause to doubt the benefits from renegotiations, this is counteracted by the broadening of PE definitions.

The replication exercise we have conducted here is only a proof of concept, and its results should certainly be tested using more sophisticated models and a wider range of data, as we discussed above. Still, its tentative conclusion suggests that WHT rates are the main drivers of any relationship between tax treaties and FDI stocks. If this result is confirmed, it would suggest that negotiators can seek the maximum protection of source taxing rights in other parts of the treaty, knowing that this is unlikely to dilute any investment-promoting impact of the treaty. Conversely, a capital-importing country that does not wish to concede substantial reductions in WHT rates may have little reason to negotiate a treaty, since without those concessions the impact of the treaty on investment could be small.

As international guidance urges lower-income countries to prepare more carefully and critically for negotiations, future research using the dataset may offer important guidance. 
TA B LE A1 - Selected Tax Treaties with Mauritius, 2001-19: A Detailed Breakdown

\begin{tabular}{|c|c|c|c|c|c|c|c|}
\hline $\begin{array}{c}\text { ARTICLE, } \\
\text { PARAGRAPH NO. }\end{array}$ & $\begin{array}{c}\text { KENYA } \\
\text { (SIGNED 2012, } \\
\text { NOT IN FORCE) }\end{array}$ & $\begin{array}{c}\text { KENYA } \\
\text { (SIGNED 2019, } \\
\text { NOT IN FORCE) }\end{array}$ & $\begin{array}{c}\text { RWANDA } \\
\text { (SIGNED 2001, } \\
\text { TERMINATED) }\end{array}$ & $\begin{array}{l}\text { RWANDA } \\
\text { (SIGNED 2013, } \\
\text { IN FORCE) }\end{array}$ & $\begin{array}{c}\text { SENEGAL } \\
\text { (SIGNED 2002, } \\
\text { TERMINATED) }\end{array}$ & $\begin{array}{c}\text { ZAMBIA } \\
\text { (SIGNED 2011, } \\
\text { TERMINATED) }\end{array}$ & $\begin{array}{l}\text { REPUBLIC OF } \\
\text { THE CONGO } \\
\text { (SIGNED 2010, } \\
\text { IN FORCE) }\end{array}$ \\
\hline $5(3)(a) S$ & YES & YES & YES & YES & YES & YES & YES \\
\hline $5(4)(b)$ & YES & NO & YES & NO & YES & YES & YES \\
\hline $5(5)(b)$ & NO & YES & NO & YES & NO & NO & NO \\
\hline $5(6)$ & YES & YES & NO & YES & YES & NO & NO \\
\hline $7(3)$ & YES & YES & YES & YES & YES & NO & YES \\
\hline $8(2)$ & NO & YES & NO & NO & NO & NO & NO \\
\hline $10(2)(a) Q, \%$ & 5 & 8 & 0 & 10 & 0 & 5 & 0 \\
\hline $10(2)(a) \mathrm{T}, \%$ & 10 & - & - & - & - & 25 & 25 \\
\hline 10(2)(b),\% & 10 & 8 & 0 & 10 & 0 & 15 & 5 \\
\hline $11(2), \%$ & 10 & 10 & 0 & 10 & 0 & 10 & 5 \\
\hline $11(2) F, \%$ & 10 & 10 & 0 & 10 & 0 & 10 & 5 \\
\hline $13(4)$ & NO & YES & NO & NO & NO & - & NO \\
\hline $13(5)$ & NO & YES & NO & NO & NO & NO & NO \\
\hline 14 & NO & NO & YES & NO & YES & YES & NO \\
\hline $16(2)$ & YES & YES & NO & NO & NO & NO & NO \\
\hline $21(3)$ & NO & YES & NO & YES & NO & NO & NO \\
\hline $25 B(5)$ & NO & NO & NO & NO & NO & NO & YES \\
\hline 27 & YES & YES & NO & YES & NO & NO & YES \\
\hline 29 & NONE & PPT & NONE & NONE & NONE & NONE & NONE \\
\hline
\end{tabular}

Source: Tax Treaties Explorer dataset, https://www.treaties.tax/.

Note: $P P T=$ principal purpose test $;-=$ not available 


\section{$>\quad$ REFERENCES}

ActionAid. 2016. "Mistreated: The Tax Treaties that Are Depriving the World's Poorest Countries of Vital Revenue." Report, ActionAid UK, London.

Alencar, H., C. Avan, and J. Olwenyi. 2020. "The Money Pipeline. Cursed by Design: How the Uganda-Netherlands Tax Agreement Is Denying Uganda a Fair Share of Oil Revenues." Case study, Oxfam, Nairobi, Kenya.

Arel-Bundock, V. 2017. "The Unintended Consequences of Bilateralism: Treaty Shopping and International Tax Policy." International Organization 71 (2): 349-71. doi:10.1017/ S0020818317000108.

Arellano, M., and S. Bond. 1991. "Some Tests of Specification for Panel Data: Monte Carlo Evidence and an Application to Employment Equations." Review of Economic Studies 58 (2): 277-97.

ATAF (African Tax Administration Forum). 2019. "The Place of Africa in the Shift towards Global Tax Governance: Can the Taxation of the Digitalised Economy $\mathrm{Be}$ an Opportunity for Morelinclusiveness?" Paper, ATAF, Pretoria, South Africa.

Azémar, C., and D. Dharmapala. 2019. "Tax Sparing Agreements, Territorial Tax Reforms, and Foreign Direct Investment." Journal of Public Economics 169: 89-108. doi:10.1016/j.jpubeco.2018.10.013.

Baker, P. L. 2014. "An Analysis of Double Taxation Treaties and their Effect on Foreign Direct Investment." International Journal of the Economics of Business 21 (3): 341-77. doi:10. 1080/13571516.2014.968454.

Balabushko, O., S. Beer, J. Loeprick, and F. Vallada. 2017. "The Direct and Indirect Costs of Tax Treaty Policy: Evidence from Ukraine." Policy Research Working Paper 7982, World Bank, Washington, DC.

Barthel, F., M. Busse, R. Krever, and E. Neumayer. 2010. "The Relationship between Double Taxation Treaties and Foreign Direct Investment." In Tax Treaties: Building Bridges between Law and Economics, edited by M. Lang, P. Pistone, J. Schuch, C. Staringer, A. Storck, and M. Zagler, 3-18. Amsterdam: International Bureau of Fiscal Documentation.

Barthel, F., M. Busse, and E. Neumayer. 2009. "The Impact of Double Taxation Treaties on Foreign Direct Investment: Evidence from Large Dyadic Panel Data." Contemporary
Economic Policy 28 (3): 366-77. doi:10.1111/j.14657287.2009.00185.x.

Barthel, F., and E. Neumayer. 2012. "Competing for Scarce Foreign Capital: Spatial Dependence in the Diffusion of Double Taxation Treaties." International Studies Quarterly 56 (4): 645-60. doi:10.1111/j.1468-2478.2012.00757.x.

Beer, S., and J. Loeprick. 2021. "Too High a Price? Tax Treaties with Investment Hubs in Sub-Saharan Africa." International Tax and Public Finance 28 (1): 113-53. doi:10.1007/s10797-020-09615-4.

Blonigen, B. A., L. Oldenski, and N. Sly. 2014. "The Differential Effects of Bilateral Tax Treaties." American Economic Journal: Economic Policy 6 (2): 1-18. doi:10.1257/pol.6.2.1.

Brooks, K. 2010. "Canada's Evolving Tax Treaty Policy toward Low-Income Countries." In Globalization and Its Tax Discontents: Tax Policy and International Investments, edited by A. J. Cockfield, 189-211. Toronto: University of Toronto Press.

Brooks, K., and R. Krever. 2015. "The Troubling Role of Tax Treaties." In Tax Design Issues Worldwide, edited by G. M. M. Michielse and V. Thuronyi, 159-78. Alphen aan den Rijn, Netherlands: Kluwer Law International.

Brown, P. A. 2020. "How Hard Can This Be? The Dearth of U.S. Tax Treaties with Latin America." University of Miami Law Review 74 (2): 359-415.

Chisik, R. and R. B. Davies. 2004. "Asymmetric FDI and Tax-Treaty Bargaining: Theory and Evidence." Journal of Public Economics 88 (6): 1119-48. doi:10.1016/s00472727(03)00059-8.

Dagan, T. 2000. "The Tax Treaties Myth." New York University Journal of International Law and Politics 32: 939-92.

Daurer, V. 2014. Tax Treaties and Developing Countries. Alphen aan den Rijn: Netherlands: Kluwer Law International.

Daurer, V., and R. Krever. 2012. "Choosing between the UN and OECD Tax Policy Models: An African Case Study." Working Paper 2012/60, Robert Schuman Centre for Advanced Studies, European University Institute, San Domenico di Fiesole, Italy. 
Dressler, D. 2012. "Form Follows Function? Evidence on Tax Savings by Multinational Holding Structures." Discussion Paper No. 12-057, ZEW Centre for European Economic Research, Mannheim, Germany.

Egger, P., and V. Merlo 2007. "The Impact of Bilateral Investment Treaties on FDI Dynamics." World Economy 30 (10): 1536-49.

Eyitayo-Oyesode, O. A. 2020. "Source-Based Taxing Rights from the OECD to the UN Model Conventions: Unavailing Efforts and an Argument for Reform." Law and Development Review 13 (1): 193-227. doi:10.1515/ldr-2018-0073.

Hearson, M. 2016. "Measuring Tax Treaty Negotiation Outcomes: The ActionAid Tax Treaties Dataset." Working Paper No. 47, International Centre for Tax and Development, Brighton, UK.

Hearson, M. 2017. "The UK-Colombia Tax Treaty: 80 Years in the Making." British Tax Review 2017 (4): 375-84.

Hearson, M. 2018. "When Do Developing Countries Negotiate Away Their Corporate Tax Base?" Journal of International Development 30 (2): 233-55.

Hearson, M. 2021. Imposing Standards: The North-South Dimension to Global Tax Politics. Ithaca, NY: Cornell University Press.

Hearson, M., and J. Kangave. 2016. "A Review of Uganda's Tax Treaties and Recommendations for Action." Working Paper No. 50, International Centre for Tax and Development, Brighton, UK.

Hong, S. 2018. "Tax Treaties and Foreign Direct Investment: A Network Approach." International Tax and Public Finance 25 (5): 1277-1320. doi:10.1007/s10797-018-9489-0.

IMF (International Monetary Fund.) 2014. "Spillovers in International Corporate Taxation." Policy paper, IMF, Washington, DC.

Irish, C. R. 1974. "International Double Taxation Agreements and Income Taxation at Source." International and Comparative Law Quarterly 23 (2): 292-316. doi:10.1093/iclqaj/23.2.292.

Janský, P., and M. Šedivý. 2018. "Estimating the Revenue Costs of Tax Treaties in Developing Countries." World Economy 42 (6): 1828-49. doi:10.1111/twec.12764.
Kangave, J. 2009. "The Dominant Voices in Double Taxation Agreements: A Critical Analysis of the 'Dividend' Article in the Agreement between Uganda and the Netherlands." International Community Law Review 11 (4): 387-407. doi:1 $0.1163 / 187197409 \times 12525781476123$.

Kennedy, P. E. 1981. "Estimation with Correctly Interpreted Dummy Variables in Semilogarithmic Equations [The Interpretation of Dummy Variables in Semilogarithmic Equations]." American Economic Review 71 (4): 801.

Leduc, S., and G. Michielse. 2021. "Are Tax Treaties Worth It for Developing Economies?" In Corporate Income Taxes under Pressure: Why Reform Is Needed and How It Could Be Designed, edited by R. de Mooij, A. Klemm, and V. Perry, 123-171. Washington, DC: International Monetary Fund. doi:10.5089/9781513511771.071.ch008.

Li, J. 2012. "The Great Fiscal Wall of China: Tax Treaties and Their Role in Defining and Defending China's Tax Base." Bulletin for International Taxation 66 (9): 452-79.

Marques, M., and C. Pinho. 2014. "Tax-Treaty Effects on Foreign Investment: Evidence from European Multinationals." FinanzArchiv 70 (4):527-55. doi:10.1628/001522114X685474.

McGauran, K. 2013. Should the Netherlands Sign Tax Treaties with Developing Countries? Amsterdam: Centre for Research on Multinational Corporations (SOMO).

Michielse, G. M. M. 2012. "Mongolia: Technical Assistance Report-Safeguarding Domestic Revenue-A Mongolian DTA Model." Country Report No. 12/306, International Monetary Fund, Washington, DC.

Mintz, J. M., and A. J. Weichenrieder. 2010. The Indirect Side of Direct Investment: Multinational Company Finance and Taxation. Cambridge, MA: MIT Press.

Mutava, C. 2019. "Review of Tax Treaty Practices and Policy Framework in Africa." Working Paper No. 102, International Centre for Tax and Development, Brighton, UK.

Nickell, S. 1981. "Biases in Dynamic Models with Fixed Effects." Econometrica 49 (6): 1417-26.

Ogembo, D. L. 2019. "The Tax Justice Network-Africa v Cabinet Secretary for National Treasury \& 2 Others: A Big Win for Tax Justice Activism?" British Tax Review (2): 105-17. 
Paolini, D., P. Pistone, G. Pulina, and M. Zagler. 2016. "Tax Treaties with Developing Countries and the Allocation of Taxing Rights." European Journal of Law and Economics 42 (3): 383-404. doi:10.1007/s10657-014-9465-9.

PCT (The Platform for Collaboration on Tax). 2020. "The Taxation of Offshore Indirect Transfers: A Toolkit." Report, PCT. https://www.oecd.org/ctp/PCT-offshore-indirect-transfersdraft-toolkit-version-2.pdf.

PCT (The Platform for Collaboration on Tax). 2021. "Toolkit on Tax Treaty Negotiations." Online publication, PCT, https:// www.tax-platform.org/publications/PCT Toolkit Tax Treaty Negotiations_Online Version.

Petkova, K., A. Stasio, and M. Zagler. 2020. "On the Relevance of Double Tax Treaties." International Tax and Public Finance 27 (3): 575-605. doi:10.1007/s10797-01909570-9.

Pistone, P. 2010. "Tax Treaties with Developing Countries: A Plea for New Allocation Rules and a Combined Legal and Economic Approach." In Tax Treaties: Building Bridges between Law and Economics, edited by M. Lang, P. Pistone, J. Schuch, C. Staringer, A. Storck, and M. Zagler, 413-40. Amsterdam: International Bureau of Fiscal Documentation.

Rixen, T. 2011. "From Double Tax Avoidance to Tax Competition: Explaining the Institutional Trajectory of International Tax Governance." Review of International Political Economy 18 (2): 197-227. doi:10.1080/09692290.2 010.481921.

Rixen, T., and P. Schwarz. 2009. "Bargaining over the Avoidance of Double Taxation: Evidence from German Tax Treaties." FinanzArchiv 65 (4): 442-71. doi:10.1628/001522109X486589.

Sauvant, K. P., and L. E. Sachs, eds. 2009. The Effect of Treaties on Foreign Direct Investment. Oxford: Oxford University Press.

Shepherd, L. A. 2013. “Don't Sign OECD Model Tax Treaties!" Tax Justice Network (blog), May 31. http://taxjustice. blogspot.ch/2013/05/lee-sheppard-dont-sign-oecd-model-tax. html.

Trepelkov, A. 2014. "The United Nations Model Double Taxation Convention in the Context of Financing for Development." PowerPoint presentation, Financing for Development Office, United Nations Department of Economic and Social Affairs (UN DESA), New York.
UN (United Nations). 2019. Manual for the Negotiation of Bilateral Tax Treaties between Developed and Developing Countries. New York: UN.

van 't Riet, M., and A. Lejour. 2018. "Optimal Tax Routing: Network Analysis of FDI Diversion." International Tax and Public Finance 25 (5): 1321-71. doi:10.1007/s10797-0189491-6.

Vega, A., and I. Rudyk. 2011. "Explaining Reservations to the OECD Model Tax Convention: An Empirical Approach." InDret 4: 1-19.

West, C. 2021. "Emerging Treaty Policies in Africa: Evidence from the African Tax Administration Forum Models." Bulletin for International Taxation 75 (1).

Weyzig, F. 2013. "Tax Treaty Shopping: Structural Determinants of Foreign Direct Investment Routed through the Netherlands." International Tax and Public Finance 20 (6): 910-37. doi:10.1007/s10797-012-9250-z.

Wijnen, W., and J. de Goede. 2014. "The UN Model in Practice 1997-2013." Bulletin for International Taxation 68 (3): $118-46$.

Wijnen, W., J. de Goede, and A. Alessi. 2012. "The Treatment of Services in Tax Treaties." Bulletin for International Taxation 66 (1): $27-38 . x^{\star}$

Zolt, E. M. 2018. "Tax Treaties and Developing Countries." Tax Law Review 72 (1): 111-51. 


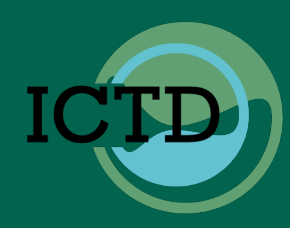

(4) WORLD BANK GROUP 